\title{
Magnetic Nanomaterials as Biocatalyst Carriers for Biomass Processing: Immobilization Strategies, Reusability, and Applications
}

\author{
Mayra A. Mariño ${ }^{1}$, Stephanie Fulaz ${ }^{2}$ (i) and Ljubica Tasic ${ }^{3, *(\mathbb{D}}$ \\ 1 Departamento de Ciencias Básicas, Unidades Tecnológicas de Santander, Av. Los Estudiantes \#9-82, \\ Bucaramanga 680005, Colombia; mamarino@correo.uts.edu.co \\ 2 Food Safety and Zoonosis, School of Veterinary Medicine and Animal Sciences, University of Copenhagen, \\ Stigbøjlen 4, 1870 Frederiksberg, Denmark; stephanie.silva@sund.ku.dk \\ 3 Laboratory of Biological Chemistry, Institute of Chemistry, University of Campinas, \\ Campinas 13083-970, SP, Brazil \\ * Correspondence: ljubica@unicamp.br; Tel.: +55-19-3521-1106
}

Citation: Mariño, M.A.; Fulaz, S.; Tasic, L. Magnetic Nanomaterials as Biocatalyst Carriers for Biomass Processing: Immobilization Strategies, Reusability, and Applications. Magnetochemistry 2021, 7, 133. https://doi.org/10.3390/ magnetochemistry7100133

Academic Editor: Lotfi Bessais

Received: 30 May 2021

Accepted: 16 September 2021

Published: 23 September 2021

Publisher's Note: MDPI stays neutral with regard to jurisdictional claims in published maps and institutional affiliations.

Copyright: (c) 2021 by the authors. Licensee MDPI, Basel, Switzerland. This article is an open access article distributed under the terms and conditions of the Creative Commons Attribution (CC BY) license (https:// creativecommons.org/licenses/by/ $4.0 /)$.

\begin{abstract}
Environmental concerns, along with oil shortages, have increased industrial interest in biomass conversion to produce biofuels and other valuable chemicals. A green option in biomass processing is the use of enzymes, such as cellulases, hemicellulases, and ligninolytic (laccase and peroxidases), which have outstanding specificity toward their substrates and can be reused if immobilized onto magnetic nanocarriers. Numerous studies report the biocatalysts' performance after covalent binding or adsorption on differently functionalized magnetic nanoparticles (MNPs). Functionalization strategies of MNPs include silica-based surfaces obtained through a sol-gel process, graphene oxide-based nanocomposites, polymer-coated surfaces, grafting polymer brushes, and others, which have been emphasized in this review of the immobilization and co-immobilization of enzymes used for biomass conversion. Careful analysis of the parameters affecting the performance of enzyme immobilization for new hybrid matrices has enabled us to achieve wider tolerance to thermal or chemical stress by these biosystems during saccharification. Additionally, it has enabled the application of immobilized laccase to remove toxic organic compounds from lignin, among other recent advances addressed here related to the use of reusable magnetic carriers for bioderived chemical manufacturing.
\end{abstract}

Keywords: nanosupport; enzymatic hydrolysis; magnetic core-shell; biomass saccharification

\section{Introduction}

Biological processes stand out for their specificity and low environmental impact, but the application of enzymes on an industrial scale requires strategies to guide bioconversions practically and cost-effectively. Among bioprocessing of plant residues, the focus is on using enzymes for hydrolysis and degradation of agro-industrial waste, wood, algae, or forestry residues. The conversion of biomass to biofuels, carbohydrates, monosaccharides, or other chemicals such as organic acids and phenolic compounds is known as a biorefinery [1]. A biorefinery consists of biomass processing, which can be performed by three different approaches: thermochemical conversion, first-generation conversion related to food derivatives (starch, glycerol, and lipids), and second-generation conversion based on lignocellulosic biomass and food waste (Figure 1). The first-generation conversion has been focused on the production of biofuels mainly through alcoholic fermentation (e.g., ethanol and butanol) and transesterification (e.g., biodiesel). It has been considered to negatively impact the global food supply and land sustainability once it uses food crops as a biomass source. In contrast, the second-generation conversion has generated many new technologies due to the challenges involved in the saccharification of lignocellulosic 
biomass, a complex, multi-component structure composed of cellulose (30-50\%), hemicellulose (25-30\%), and lignin (15-20\%). Cellulose is tied together in microfibrils that are surrounded by lignin and linked by hemicellulose. Despite being an abundantly available organic resource, lignocellulosic biomass is still under-explored due to the intricate and costly process of converting it to sugars, which can then be fermented. Lignocellulosic biomass can be hydrolyzed by acid or enzymatic catalysts. The use of biocatalysts has been highlighted by the hydrolytic capacity of the enzymes secreted by filamentous fungi such as the genus Trichoderma and Aspergillus. These extracellular enzymes are mainly cellulases and xylanases, which can be concentrated through separation methods and have high performance to hydrolyze the components of lignocellulose [1]. In addition, laccases have been used for the treatment of polluting effluents from the biorefinery and textile industrial dyes and products from pharmaceutical companies, among other pollutants, from wastewater $[2,3]$. On the other hand, the challenge for biocatalysts in engineering has been to control product distribution since biomass processing generates liquid and solid products derived from crystalline cellulose and lignin.

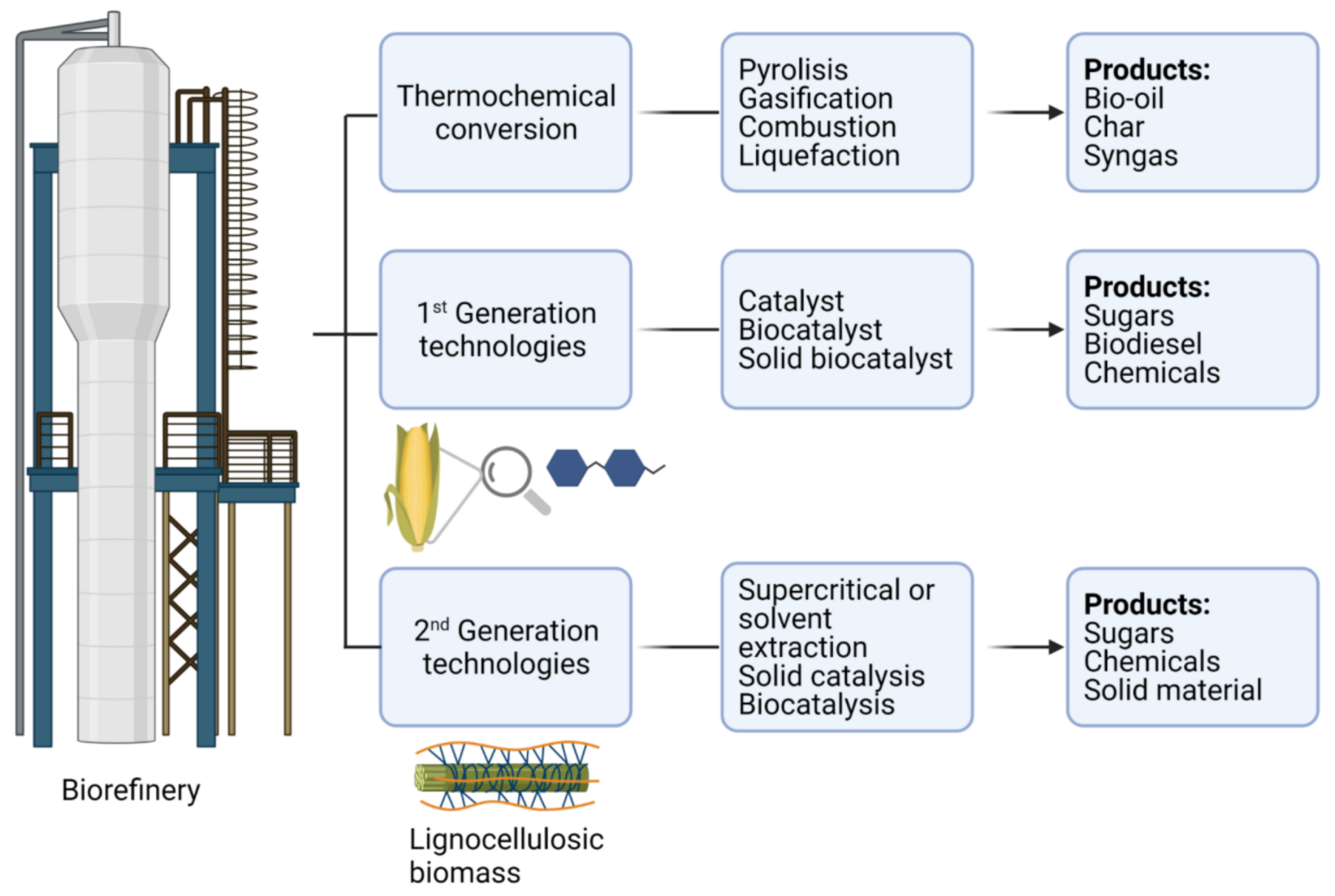

Figure 1. Biorefinery technologies according to different approaches.

In this context, using magnetic support, enzyme immobilization has opened the possibility of using solid biocatalysts, allowing for enzyme recovery, extending their use in continuous mode, and providing protection against thermal and chemical changes during storage or manufacturing. Lignin derivatives are cellulase inhibitors, so magnetic separation strengthens their performance by removing the solid phase and, finally, recovering the fermentable sugars [1]. Moreover, the use of nanobiocatalysts bridge the gap between heterogeneous catalysis with its advantages of easy recovery and recyclability, and homogeneous catalysis' high activity, owing to the nanoparticle size, which increases mass-transfer rates.

In addition, biomass enzymatic processing is an application of green chemistry with highlighted environmental benefits and sustainable economics, such as mild reaction conditions, low-load effluents, low energy demand, high specificity, and valuable products. These advantages usually entail long reaction times, so that their application has been hampered on an industrial level. Although enzyme immobilization has been one of the 
most studied alternatives, once this technique effectively increases the stability and half-life of biocatalysts [4], it is still not widely applied, mainly because multiple factors impact the performance of enzymatic immobilization, such as multipoint attachment to the carrier, unsuitable spacer arm, or diffusion constraints generated by the carrier's physical structure, among others [5].

Covalent immobilization of enzymes attached to a magnetic core is one strategy that has offered high stability to enzymes during biomass processing, coupled with several benefitsfor instance, easy separation of products from a liquid stream, better inhibition tolerance, and reduction of enzyme leachates. Further, covalent immobilization using magnetic nanoparticles is suitable for bioprocessing lignocellulose because it overcomes the bottleneck associated with the accessibility of the insoluble substrate to the active site of cellulases, laccases, and xylanases. Moreover, covalent immobilization between a nanocarrier and an enzyme through a spacer arm decreases the steric hindrance compared with other immobilization techniques, such as encapsulation in gels, cross linked enzymes, entrapment, or a porous micro-carrier [6,7]. Magnetic separation has allowed the recovery of many enzymes from an aqueous media by a simplified operational step using an external magnetic field. The chemical designs related to magnetic systems with covalently linked or adsorbed enzymes of interest are addressed here. We also overview immobilized enzyme reusability findings during biomass processing for biofuel production and value-added chemicals.

The reactivity of magnetic nanoparticles (MNPs) for the biocatalysis of lignocellulosic biomass is also addressed, which has been exploited mainly in reversible immobilization through ion exchange and irreversible immobilization by covalent bonding after amine-terminated core-shell coating using hybrid matrices and crosslinking. The magnetic properties of the supports are preserved after functionalization, and coating with a biopolymer leads to MNP toxicity reduction [8]. Finally, the overall performance of lignocellulose processing is discussed, emphasizing the use of nanotechnology coupled with bioreactors and highlighting principal parameters, such as colloidal stability, protein loading, and reusability of the solid biocatalyst.

\section{Synthesis of Magnetic Nanoparticles Used as Biocatalyst Carriers for Biomass Conversion}

Magnetic nanoparticles have found innumerous applications in different sectors, gaining a lot of attention due to their applications in biosensing, drug delivery, catalysis, wastewater treatment, medicine, and others. Therefore, extensive research has focused on the development of different synthetic routes to obtain MNPs with optimum characteristics (e.g., size, shape, stability, and biocompatibility). The methods are commonly divided amongst chemical, physical, and biological routes, and the most often used are coprecipitation, thermal decomposition, ball milling, hydrothermal, micro-emulsion, sol-gel, and biological methods (Figure 2). Physical methods are based on two different approaches: "top-down", where bulk materials are broken into nano-sized particles, such as ball milling, and "bottom-up", where nano-scaled particles are obtained by, for example, laser evaporation. Chemical methods are primarily based on bottom-up approaches [9]. Co-precipitation is the most frequently used to produce MNPs with controlled size and magnetic properties. In this method, metal ions are dissolved in a solvent and a precipitant is added, leading to nanoparticle formation. In the thermal decomposition method, organometallic precursors are exposed to extreme temperatures to form monodisperse MNPs. 

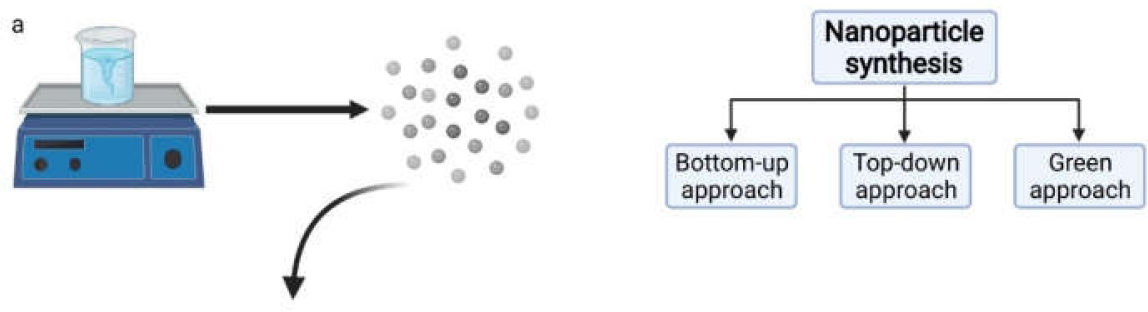

b
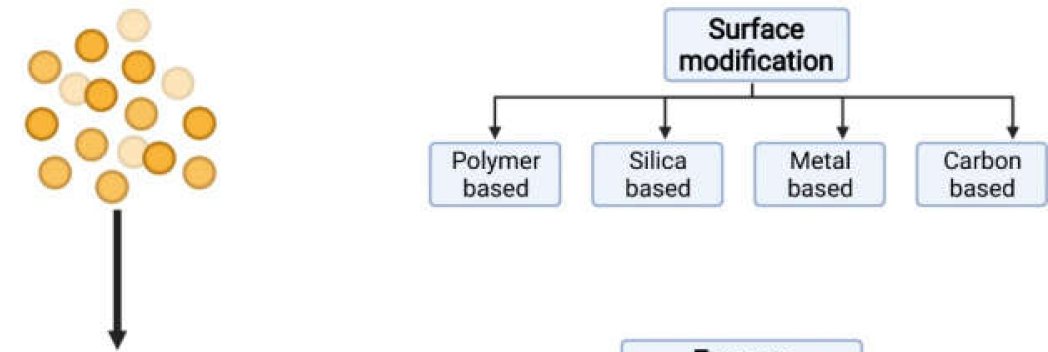

c
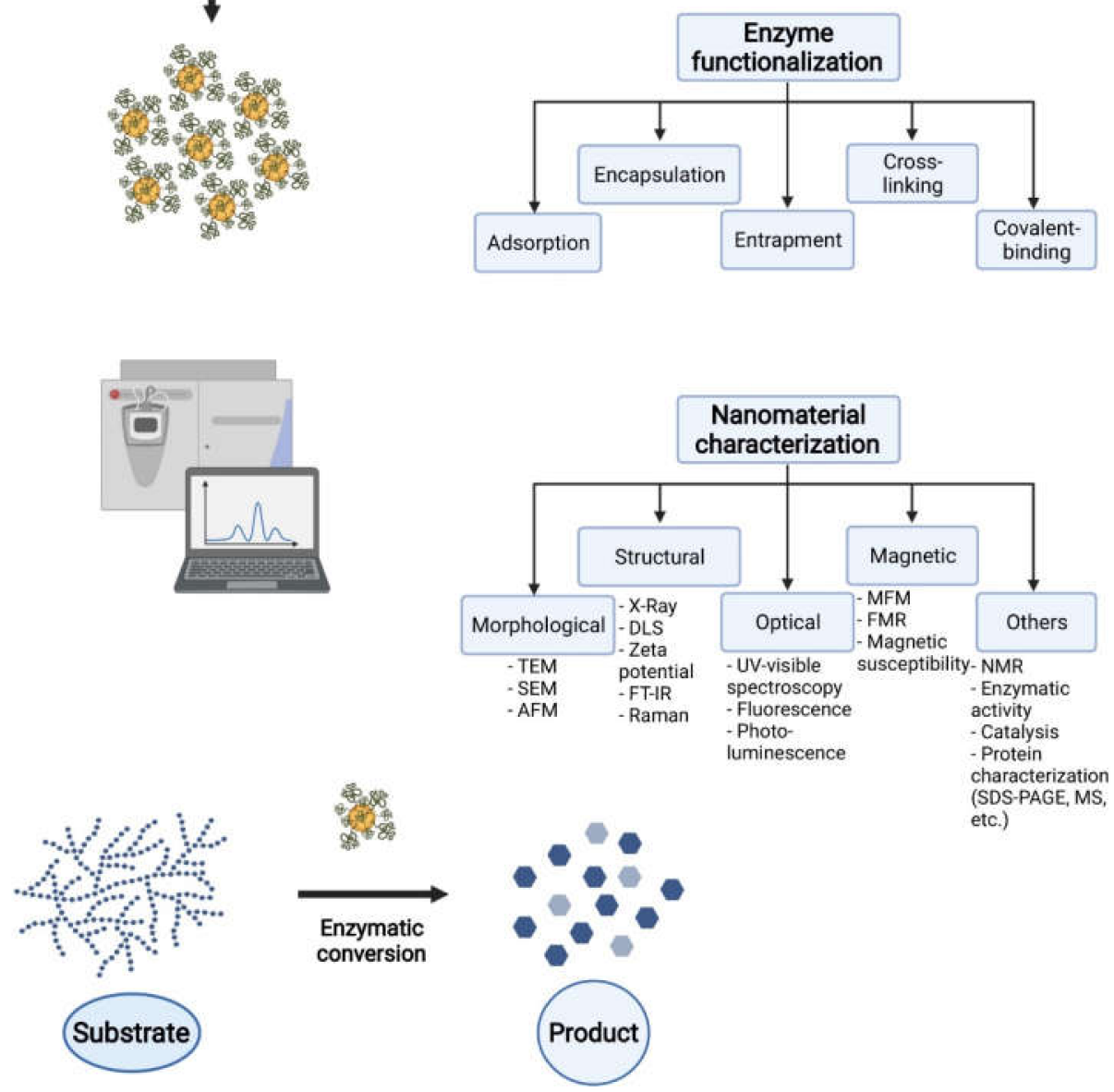
(SDS-PAGE, MS,

Figure 2. Illustration of the main steps for synthesis (a-c), characterization (d), and application (e) of an immobilized enzyme on a nanomagnet, forming an MNP biocatalyst. The synthesis of this product starts with (a) magnetic core synthesis, then (b) the best coating substance is chosen for the MNP surface modification for (c) suitable functionalization with a target enzyme. In a nanomaterial's characterization (d), it is important to determine the enzyme load and activity. (e) The MNP biocatalyst must retain activity toward its substrate in repeated steps after recovery.

The synthesis of magnetic nanoparticles (Figure 2) is one of the most challenging process stages. It determines the shape, particle size, and composition of the surface, thus defining its magnetic properties. In magnetite production, the chemical route by co-precipitation is usually preferred for its simplicity, efficiency, and reproducibility. It is a 
fast and straightforward method to obtain MNPs at a low temperature (generally $70{ }^{\circ} \mathrm{C}$ ) following the reaction:

$$
\mathrm{Fe}^{+2}+2 \mathrm{Fe}^{+3}+8 \mathrm{OH}^{-} \leftrightarrow \mathrm{Fe}(\mathrm{OH})_{2}+2 \mathrm{Fe}(\mathrm{OH})_{3} \rightarrow \mathrm{Fe}_{3} \mathrm{O}_{4}+4 \mathrm{H}_{2} \mathrm{O}
$$

A molar ratio of 1:2 is used for $\mathrm{Fe}^{+2} / \mathrm{Fe}^{+3}$ to obtain magnetite in an alkaline medium ( $\mathrm{pH} 8$ to 14) under an inert atmosphere that protects the $\mathrm{Fe}_{3} \mathrm{O}_{4}$ nanoparticles from being oxidized and reduces particle size in an aqueous solution. Although this method has low kinetic control over the size of the nanoparticles, some modifications have emerged to prevent aggregation or slow down nucleation, such as the control of the kinetic factor through adequate control of vigorous shaking and a short reaction time. A good alternative for size-tune spherical MNPs is the use of a mild oxidant (e.g., nitrate ions) and/or capping agents that stabilize the particles to avoid their agglomeration or reduction, such as ethylene glycol, polyethylene glycol (PEG), polyvinyl alcohol (PVA) or oleic acid. Stoichiometric amounts are also a crucial parameter for obtaining homogeneous particle sizes for alloybased materials such as spinel ferrite $\mathrm{CoFe}_{2} \mathrm{O}_{4}$ or $\mathrm{ZnFe}_{2} \mathrm{O}_{4}$ [10].

The synthesis by thermal decomposition of precursors has allowed for size control and narrow size distributions in the presence of organic surfactants such as octylamine and oleic acid. Maghemite and magnetite nanocrystals synthesized by this method present sizes in the 3-20 nm range at high temperatures (e.g., 250-300 ${ }^{\circ} \mathrm{C}$ ) [11]. At lower temperatures (e.g., $150^{\circ} \mathrm{C}$ ), MNPs with diameters up to $20 \mathrm{~nm}$ are obtained by a hydrothermal method using an autoclave without surfactants. Magnetite and zinc ferrite NPs with diameters of $40 \mathrm{~nm}$ were obtained by adding a mild oxidant to the aqueous solutions after autoclaving the precipitates for $12 \mathrm{~h}[11,12]$.

Biological synthesis is a known method for synthesizing MNPs using plants, bacteria, fungi, viruses, and actinomycetes [13]. The green method is often preferred because it produces biocompatible nanoparticles, and it is a sustainable, safe, and clean process. MNPs produced by plants, microbes, and algae have been described with distinct shapes (e.g., cubic, tetragonal, spherical, elliptical, cylindrical, rods, etc.). In addition, the biomaterials act as reducing, capping, and stabilizing agents in the green synthesis of nanoparticles. For more information regarding the green synthesis of iron oxide nanoparticles, go to [14].

MNPs are sensitive to oxidation in an acidic medium and might aggregate, thus losing their superparamagnetic properties, so a polymer coating is usually performed using chitosan, polyvinyl alcohol (PVA), and grafting with polyacrylic acid (PAA). Another route is based on silica gel-mediated organic synthesis. Metal alkoxides in the sol-gel technique, such as tetraethylorthosilicate (TEOS), are widely used in the silanization or condensation processes of silanol groups, also called the sol-gel method. Different organic or inorganic coating, grafting, or condensation approaches are described in Figure 3, highlighting the importance of surface functionalization of MNPs to provide the surface with active groups. These functional groups are used in enzyme immobilization by forming covalent bonds or physical adsorption, yielding reusable magnetic biocatalysts [15].

\section{Characterization of Magnetic Nanoparticles}

Nanoparticles' optical, thermal, and magnetic properties are dependent on nanoparticle size, charge, and surface functionalization. Therefore, to be effectively used, their physicochemical characteristics, such as composition, size, surface charge, functional groups, and loading capacity, need to be evaluated carefully. 

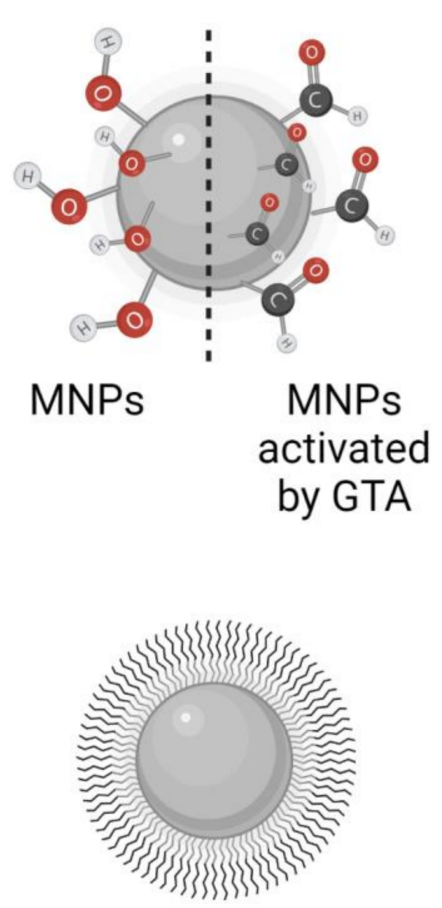

Polymer grafted MNPs
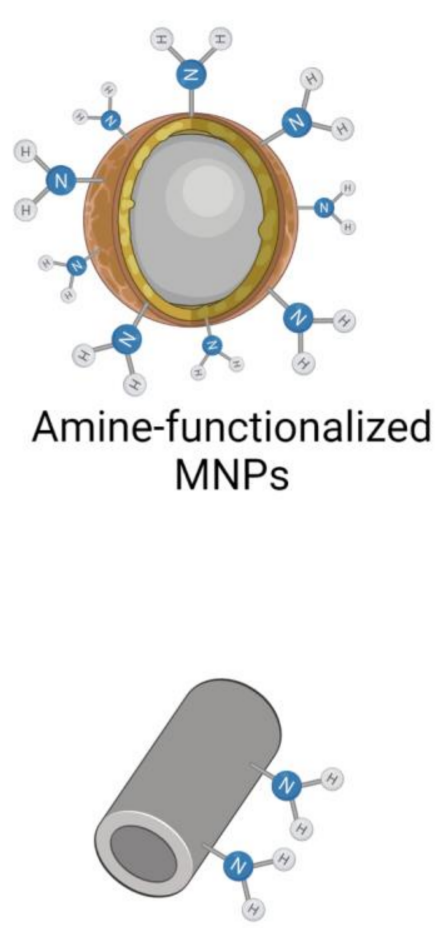

Amine-functionalized
magnetic nanotube

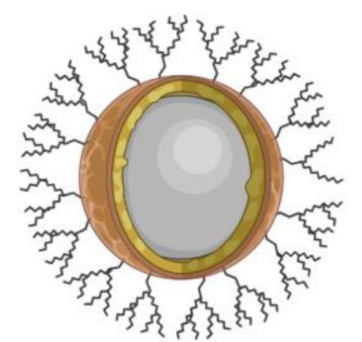

Amine-functionalized
silica or polymer coated
MNPs

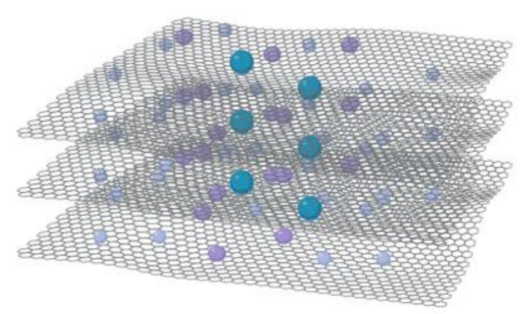

Magnetic graphene oxide sheets

Figure 3. Configurations of amine-terminated MNPs tested as reusable biocatalysts for biomass processing.

A crucial factor of nanotechnology is colloidal stability or suspension stability, which is related to particle size and charge and is used to predict aggregation/sedimentation in a specific medium (solvent effect). Dynamic light scattering is usually used to measure nanoparticles' size and size distribution and follow their stability over time and under different conditions [16]. Often, it is technically challenging to obtain homogeneous nanoparticle suspensions, so synthesis and modifications need to be optimized. Thermodynamic and kinetic factors contribute to dispersed phase stability, but particles with zeta potential (ZP) higher than $\pm 30 \mathrm{mV}$ are considered colloidally stable (without long-term size variation). Thus, zeta potentialis a practical parameter often used to predict the stability of nanoparticle suspensions. Colloids can be classified as having relatively low stability $(\mathrm{ZP}< \pm 10-20 \mathrm{mV})$, moderately low stability $( \pm 20>\mathrm{ZP}< \pm 30 \mathrm{mV})$, good stability $(\mathrm{ZP}> \pm 30 \mathrm{mV})$, or excellent stability $(\mathrm{ZP}> \pm 60 \mathrm{mV})$ [17].

The extrinsic characteristics of MNPs (Figure 2), such as size and shape, are usually studied by scanning electron microscopy (SEM) and transmission electron microscopy (TEM). At the same time, their main intrinsic properties, for example, ferromagnetic density, are measured via mass saturation magnetization $\left(M_{S}\right)$ using a vibrating sample magnetometer and crystal structure by X-ray diffraction (source: $\mathrm{Cu} \mathrm{K} \alpha$ at $40 \mathrm{kV}$ and $30 \mathrm{~mA}$ ).

The average size for magnetic nanoparticles is in the range of $10-40 \mathrm{~nm}$ for the spherical MNPs, while saturation magnetization values for functionalized MNPs are often between 32-54 emu g ${ }^{-1}[12,18]$. Bare $\mathrm{Fe}_{3} \mathrm{O}_{4} \mathrm{NPs}$ presented variations at $60-80 \mathrm{emu}$ $\mathrm{g}^{-1}[18,19]$, while $\mathrm{CoFe}_{2} \mathrm{O}_{4} \mathrm{NPs}$ and magnetized graphene oxide presented $\mathrm{M}_{\mathrm{S}}$ values in the range $40-46 \mathrm{emu} \mathrm{g}^{-1}[19,20]$. The lowest value, of $25 \mathrm{emu} \mathrm{g}^{-1}$, was obtained for copper ferrite NPs [21].

Superparamagnetic nanoparticles (MNPs) usually present average sizes in the 10-40 nm range along with a highlighted magnetic moment. Their magnetic properties depend on the size of the nanoparticles, and they start to have superparamagnetic properties when nanoparticles reach a specific diameter known as the critical diameter (Ds). The reduction in particle size leads to a rise in coercivity (Hc) up to a maximum value 
when the critical diameter (Ds) is reached (Figure 4). All magnetic spins point in the same direction and nanoparticles become difficult to demagnetize due to the high coercivity. However, if the size is further reduced, the coercivity is rapidly decreased until it reaches zero and the nanoparticles reach a superparamagnetic state [22].

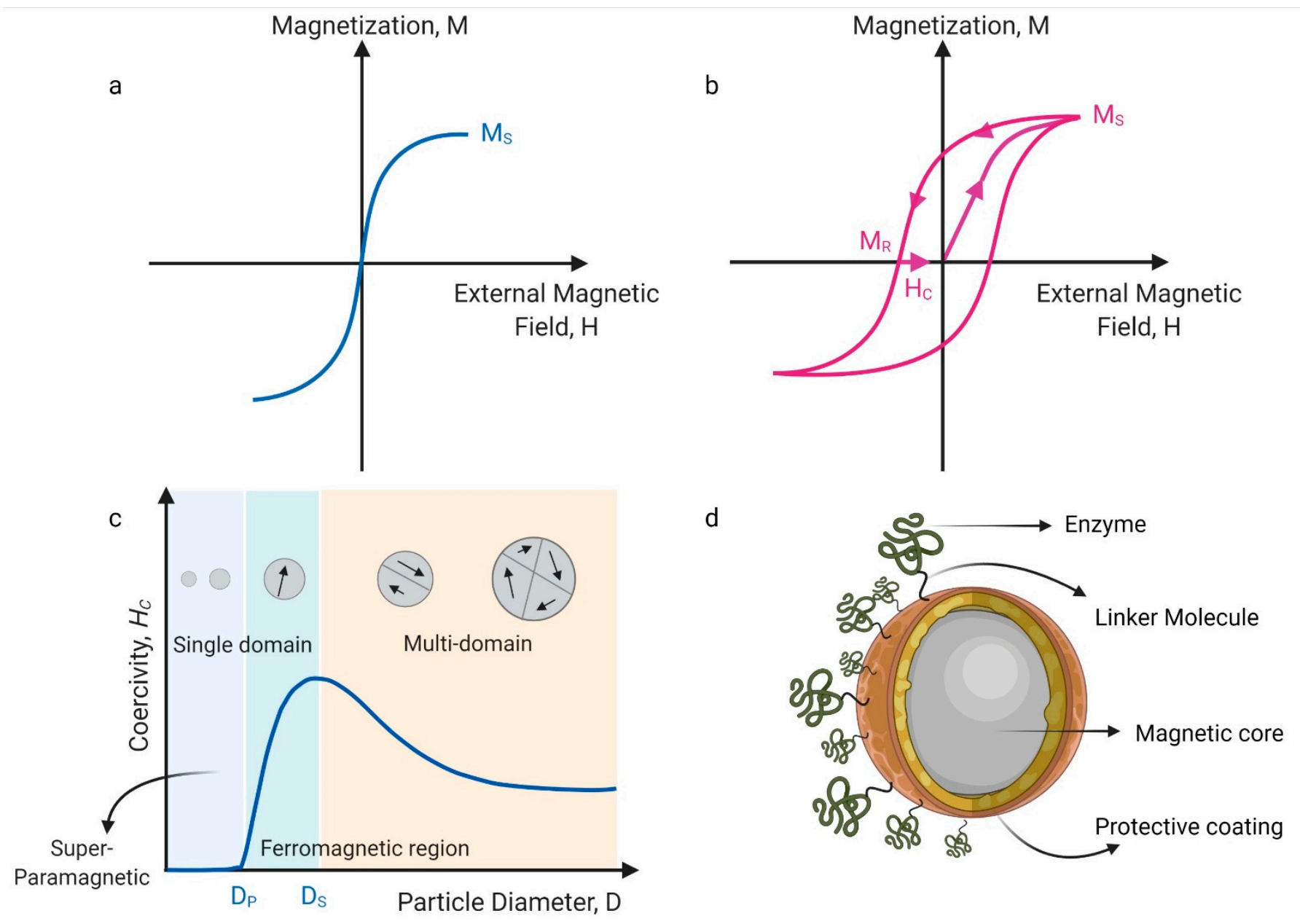

Figure 4. Illustration of magnetic nanoparticles' physical properties: (a) an ideal MNP magnetism in an external magnetic field, (b) a real magnetism, where some MNPs agglomerate because of the magnetization and coercivity. $\mathrm{M}_{\mathrm{S}}$ is saturation magnetization, $\mathrm{M}_{\mathrm{R}}$ is a remnant magnetization, and $\mathrm{H}_{\mathrm{C}}$ is coercivity, (c) small MNPs show fast response to an external magnetic field because of their size and a lower energy barrier that allows coherent and independent vectorial rotation. MNPs are difficult to demagnetize. (d) MNP typical structure shows a magnetic core, an inert shell, and enzymes attached to the MNP surface using a suitable linker.

Superparamagnetic behavior results from a lower energy barrier that allows coherent and independent vectorial rotation by applying a magnetic field. In contrast, in a bulk magnetic material, the anisotropy energy is governed by the alignment of single domains associated with a hysteresis loop with increased energy restrictions and coercivity [23], as represented in Figure 4.

Other crucial aspects in MNPs characterization are biocompatibility, enzyme loading, catalytic rates, recycling ability, and toxicity effects on microbial cells. Biomass processing starts with conversion to simple sugars, followed by fermentation to produce the desired products. It is therefore important to determine their toxicity towards microorganisms involved in the later stages of biomass processing, but also to consider their release to the environment and their impact on the natural biota. Nanoparticles' toxicity is attributed to their high surface area to volume ratio, specific chemical composition, size, charge, dosage, retention, and degradation products. Positively charged nanoparticles have often 
been reported as toxic towards bacterial cells, while MNPs have been reported to trigger neurobehavioral changes in plants and cell lines [24].

For a more in-depth study of magnetic nanoparticle characterization, the reader is referred to $[9,25,26]$.

\section{Enzyme Immobilization Strategies Involving Magnetic Nanocarriers for Biomass Conversion}

The natural degradation of biomass involves a group of enzymes known as glycoside hydrolases (EG 3.2.1.X), which act over glycosidic bonds in starch (amylases), cellulose ( $\beta$-glucosidases, endoglucanases, and exoglucanases), and hemicellulose (xylanases, $\beta$ mannanases, $\beta$-xylosidases, arabinofuranosidases, among others). Additionally, delignification counts on laccases for oxidation of the lignin from biomass, which belong to the enzyme family of multi-copper oxidases (MCOs, EC 1.10.3.2), besides lignin peroxidases and manganese peroxidases that belong to the family of oxidoreductases (EC 1.11.1.X). All these enzymes are produced by bacterial and fungal strains [6], although some insects present digestive systems with biomass-degrading potential, such as cellulases in termites [27].

\subsection{Immobilization and Co-Immobilization of Cellulose-Degrading Enzymes Using Silica-Based Carriers}

The conversion of bulk chemicals derived from lignocellulose into value-added products has been a growing interest in biorefinery. A complete bioconversion of cellulose to glucose requires three groups of enzymes acting in a synergistic mode, known as (i) Endoglucanases (EG 3.2.1.4), (ii) Exoglucanases (EC 3.2.1.91) and (iii) $\beta$-Glucosidases (EC 3.2.1.21). Endoglucanases randomly reduce internal polymer chains and release insoluble cellulose oligosaccharides and soluble cellodextrins. Their actions cause a significant decrease in the degree of polymerization, resulting in oligosaccharides with free chain ends. Exoglucanases, also called cellobiohydrolases, cleave external glycosidic bonds from non-reducing ends of cellulose or cello-oligomers, releasing small oligosaccharides such as cellobiose. $\beta$-Glucosidases act on cellobiose and cellodextrins to release D-glucose and control cellobiose inhibition [28]. Fungal enzymes are the most used in industrial applications, and we highlight Trichoderma and Aspergillus fungi as rich sources of cellulolytic complexes. T. harzianum, T. reesei and $A$. niger have great potential to secrete multifunctional cellulases that degrade the plant cell wall. Cellulose-degrading enzymes have been widely studied; thus, various magnetic materials based on silica and covalent immobilization techniques have been developed to date.

Core-shell functionalized MNPs have been mainly coated with silica and/or condensated by organosilanes on the surface, which are strategies used for enzyme immobilization and co-immobilization via Schiff base using a crosslinking agent. The first attempt was reported by Shinkai et al. [29] for amine functionalization of MNPs using (3-aminopropyl)triethoxysilane (3-APTES) in toluene for $50 \mathrm{~min}$. These activated nanoparticles were covalently linked to hydrolases, such as $\beta$-glucosidase $\left(168 \mathrm{mg} \mathrm{g}^{-1}\right)$, $\beta$-fructosidase $\left(141 \mathrm{mg} \mathrm{g}^{-1}\right), \beta$-galactosidase $\left(119 \mathrm{mg} \mathrm{g}^{-1}\right)$, and $\alpha$-amylase $\left(202 \mathrm{mg} \mathrm{g}^{-1}\right)$. This publication is a pioneer in the covalent immobilization of glycosyl hydrolases onto magnetic biocatalysts, besides showing for the first time a new method to size-tune MNPs using $\mathrm{FeSO}_{4} \mathrm{H}_{2} \mathrm{O} / \mathrm{NaNO}_{2}$ and oleic acid/water as dispersing media. A ferrofluid with the average size of $4 \mathrm{~nm}, 10 \mathrm{~nm}$, and $70 \mathrm{~nm}$ was prepared using $\mathrm{Fe}^{2+} / \mathrm{NO}^{2+}$ molar ratios of 2, 6, and 60, respectively. Another crucial step was activating MNPs using 20\% of 3-APTES and at least 3\% glutaraldehyde (GTA) solution, showing that covalently immobilized $\beta$-glucosidase maintained a higher than $90 \%$ relative activity. The subsequent studies continued to evaluate the covalent bonding of $\beta$-glucosidase on MNPs activated by the GTA solution. Verma et al. [11] synthesized MNPs using a hydrothermal method at $120^{\circ} \mathrm{C}$ for $12 \mathrm{~h}$. This method resulted in thermostability of up to $70^{\circ} \mathrm{C}$, but the reusability of the immobilized enzyme was not determined by supplementation with a cellulosic substrate. However, Valenzuela et al. [30] studied the supplementation of immobilized 
$\beta$-glucosidase from T. reesei to saccharify pretreated wheat straw and Eucalyptus globulus pulps. First, MNPs with an average diameter of $10 \mathrm{~nm}$ were prepared by co-precipitation of $\mathrm{Fe}^{+2} / \mathrm{Fe}^{+3}$ at a molar ratio of 1:2 in an aqueous solution. Next, the surface of the carrier was modified with 3-APTES in ethanol overnight. The second activation step occurred in $5 \%$ GTA $50 \mathrm{mmol} \mathrm{L}^{-1}$ solution, and, finally, the $\beta$-glucosidase was bound overnight at room temperature. Cho and colleagues [18] studied the reusability of co-immobilization on gold-doped magnetic silica nanoparticles. For their manufacture, magnetite NPs were coated with silica using tetraethyl orthosilicate (TEOS) and then functionalized with thiol with mercaptopropyltrimethoxysilane (MPTS). Both processes were carried out under reflux for $24 \mathrm{~h}$. Additionally, gold nanoparticle seeds (AuNPs) with a size of about $10 \mathrm{~nm}$ were prepared. Finally, suspensions of each nanomaterial were mixed for $24 \mathrm{~h}$ to achieve the deposition of AuNP that resulted in SH-functionalized support (Au-MSNPs), which attracted the cysteine-containing proteins. Alahakoon et al. [31] reported the activation of amine-functionalized MNPs as a step before immobilization using an aldehyde (10\% GTA solution). Even though the immobilization capacity of this support was deficient, only $23.5 \%$ of activity decreased after six hydrolysis cycles of $24 \mathrm{~h}$.

A comparative study between two cross-linking agents showed that cyanuric chloride was more efficient in retaining hydrolytic activity during the co-immobilization of cellulases Cellic ${ }^{\circledR}$ Ctec 2 than poly-glutaraldehyde using commercial superparamagnetic microparticles [32]. However, due to the smaller surface area of the micro-sized particles, the loading capacity was lower than MNPs, $11-15 \mathrm{mg}$ of bound protein per $\mathrm{g}$ of the carrier, while for MNPs, the load was higher than $100 \mathrm{mg} \mathrm{g}^{-1}$.

Abraham and co-workers [12] presented co-immobilized cellulases on MNP-doped zinc with extended storage and better thermal stability than free enzymes. The commercial enzymes from T. reesei were covalently bound by GTA solution, while the carrier was prepared by a hydrothermal method $\left(150^{\circ} \mathrm{C}\right.$ for $\left.12 \mathrm{~h}\right)$. Zhang et al. [33] compared three types of functionalization by condensation of MNPs with amino-silanes. The ability to covalently bind enzymes was compared for nanocarriers obtained by condensation with 3-APTES, 3-(2-aminoethylaminopropyl)-trimethoxysilane (3-AEAPTMES), and with 3-(2-aminoethylaminopropyl)-triethoxysilane (3-AEAPTES). The functionalization that included methoxy groups, as with 3-AEPTMES, showed greater capacity, managing to retain $87 \%$ of activity. In addition to the higher stability of cellulase activities in the face of temperature and $\mathrm{pH}$ changes compared to free enzymes, better stability in suspension (ZP: $+29 \mathrm{mV}$ ) and a higher protein capacity of $112 \mathrm{mg}$ per $\mathrm{g}$ of support were also reported. The immobilized support size was not described, nor was there a reusability study. Subsequent studies have focused on the amine functionalization of MNPs using 3-APTES. Zhang et al. [19] polymerized 3-APTES molecules directly onto MNPs at $4{ }^{\circ} \mathrm{C}$ for $2 \mathrm{~h}$ and then immobilized the cellulases (Novozymes) with $2 \%$ GTA solution for $3 \mathrm{~h}$. The immobilization performance was significant, between $84-99 \%$, as the parameters during the immobilization process were evaluated. The results showed that a concentration of GTA higher than $2 \%$ decreases the enzymatic activity. A yield of $99.1 \%$ of enzymatic activity corresponding to $161 \mathrm{mg} \mathrm{g}^{-1}$ was obtained by controlling parameters such as $\mathrm{pH}$, temperature, and incubation time. After $100 \mathrm{~h}$ of pretreated corn cob hydrolysis, activity decreased by $45 \%$. Another investigation used Trichoderma longibrachiatum cellulases bound to an amino-silane magnetic nanocarrier synthesized with TEOS and 3-APTES simultaneously for $24 \mathrm{~h}$. The enzymes were used for $56 \mathrm{~h}$ to hydrolyze pretreated Sesbania aculeata at $30^{\circ} \mathrm{C}$, and the activity decreased by $40 \%$ after $15 \mathrm{~h}$ [34].

A magnetic core of cobalt ferrite $\left(\mathrm{CoFe}_{2} \mathrm{O}_{4}\right)$ synthesized by Bohara et al. [20] was amine-functionalized via $\mathrm{N}$-(3-dimethylaminopropyl)- $\mathrm{N}^{\prime}$-ethylcarbodiimide hydrochloride (EDC) and $N$-hydroxysuccinimide (NHS) coupling reaction. Relative activity of $100 \%$ was obtained using a low protein concentration, and immobilized cellulase exhibited a better tolerance to changes in $\mathrm{pH}$ than free cellulase. The reusability of immobilized cellulase showed $36 \%$ reduced activity after six cycles of cellulose hydrolysis. 
Jia et al. [35] addressed a different enzymatic conformation, magnetic cross-linked cellulase aggregates (CLEAs) used for hydrolysis of pretreated bamboo. Magnetic-cellulaseCLEAs were composed of amine-functionalized MNPs (APTES, $90{ }^{\circ} \mathrm{C}$ for $6 \mathrm{~h}$ ) that were later used to bind precipitated cellulases with 1\% GTA solution for $3 \mathrm{~h}$ (optimal concentration previously determined). Five precipitating agents were evaluated for the previous precipitation step: isopropanol, tert-butanol, acetonitrile, polyethylene glycol 1000 (PEG1000), and ammonium sulfate. The use of isopropanol at $4{ }^{\circ} \mathrm{C}$ for $30 \mathrm{~min}$ showed a higher activity recovery after precipitating the cellulases. This strategy presented a high yield of bound protein $\left(176 \mathrm{mg} \mathrm{g}^{-1}\right)$; however, reusability results after four $24 \mathrm{~h}$ cycles of pretreated bamboo hydrolysis during $24 \mathrm{~h}$ corresponded to $62 \%$ reduced activity.

Cellulase from $A$. niger and lysozyme had been co-immobilized on silica-coated and amine-functionalized MNPs to cell-wall disruption of microalgal Nannochloropsis, so lipid extraction was enhanced, improving thermal stability and $\mathrm{pH}$ tolerance of immobilized enzymes. The immobilizing conditions were investigated, resulting in higher recovery activities when parameters such as incubation time and cellulase/lysozyme ratio were controlled. Lipids from microalgal biomass are usually transformed into biodiesel and glucose into bioethanol [36].

Sillu \& Agnihotri [37] developed magnetic halloysite nanotubes (MHNTs), a different conformation consisting of silica-based nanotubes of $\mathrm{Al}_{2} \mathrm{SiO}_{5}(\mathrm{OH})_{4} \cdot 2 \mathrm{H}_{2} \mathrm{O}$ that present silanol (-Si-OH) and siloxane groups (-Si-O-Si-) at the surface. The first step was the coating of MNPs in situ with halloysite nanotubes; then, it was grafted with amino groups using 3-APTES and activated, resulting in protein loading of $80.48 \%$ and cellulase activity yield of about $93.5 \%$. Through an experimental design, the ideal variables for enzyme immobilization were estimated as $\mathrm{pH} 5.5$, enzyme concentration of $2.5 \mathrm{mg} \mathrm{mL}^{-1}$, and $30 \mathrm{mg}$ of MHTNs. In addition, the nanocarrier was finally tested during the hydrolysis of pretreated sugarcane bagasse in the presence of ionic liquid 1-butyl-3-methylimidazolium chloride $([\mathrm{Bmim}][\mathrm{Cl}])$, which resulted in $31.8 \%$ reduced activity after seven $48 \mathrm{~h}$ cycles.

Cellulose-degrading enzymes are an essential step in the biorefinery process to convert biomass, therefore, numerous approaches involving magnetic nanocarriers have been studied as previously described and are summarized in Table 1.

\subsection{Immobilization and Co-Immobilization of Cellulose-Degrading Enzymes Polymer-Based}

Polymer nanostructures are promising materials for enzyme immobilization, either for coating or grafting. Their beneficial properties include colloidal and mechanical stability and the possibility of biodegradability and ionic adsorption [38].

Subsequent studies have focused on the immobilization of cellulases using polymers for the complete saccharification of pretreated biomass. A report [39] on three freezingthawing cycles of polyvinyl alcohol (PVA) with $\mathrm{Fe}_{2} \mathrm{O}_{3}-\mathrm{MNPs}$ described immobilization of cellulases in a water-in-oil emulsion. This micro-emulsion system yielded a spherical enzymatic complex with sizes of around $270 \mathrm{~nm}$, which was evaluated during the hydrolysis of microcrystalline cellulose. Enzyme activity dropped to $40 \%$ after four $6 \mathrm{~h}$ cycles at room temperature in a ball mill reactor. However, the energy demands and efficiency must be improved, while its leaching was not evaluated. 
Table 1. Selected procedures of functionalized MNPs using cellulose-degrading enzymes and silica derivatives.

\begin{tabular}{|c|c|c|c|c|}
\hline Enzyme & Magnetic Carrier & Carrier Size/M $\mathbf{S}$ & Results & Reference \\
\hline $\begin{array}{l}\beta \text {-Glucosidase from } \\
\text { almond }\end{array}$ & $\begin{array}{l}\text { Amine-functionalized } \\
\qquad \mathrm{Fe}_{3} \mathrm{O}_{4} \mathrm{NPs}\end{array}$ & $\begin{array}{l}4-70 \mathrm{~nm} \\
\mathrm{M}_{\mathrm{S}}: \mathrm{ND}\end{array}$ & $\begin{array}{c}70 \% \text { of activity remained after } \\
5 \text { months at } 4^{\circ} \mathrm{C} . \\
\text { Protein loading: } 168 \mathrm{mg} \mathrm{g}^{-1}\end{array}$ & $\begin{array}{c}\text { Shinkai et al. (1991) } \\
\text { [29] }\end{array}$ \\
\hline $\begin{array}{c}\beta \text {-Glucosidase from } \\
\text { A. niger }\end{array}$ & $\begin{array}{l}\text { Amine-functionalized } \\
\mathrm{Fe}_{3} \mathrm{O}_{4} \mathrm{NPs}\end{array}$ & $\begin{array}{c}40 \mathrm{~nm} \\
\mathrm{M}_{\mathrm{S}}: \mathrm{ND}\end{array}$ & $\begin{array}{l}20 \% \text { decreased activity over } \\
\text { eight } 10 \text { min cycles } \\
\text { Protein loading: } 93 \%\end{array}$ & $\begin{array}{l}\text { Verma et al. (2013) } \\
\text { [11] }\end{array}$ \\
\hline $\begin{array}{l}\beta \text {-Glucosidase from } T \text {. } \\
\text { reesei }\end{array}$ & $\begin{array}{l}\text { Amine-functionalized } \\
\mathrm{Fe}_{3} \mathrm{O}_{4} \mathrm{NPs}\end{array}$ & $\begin{array}{c}10 \mathrm{~nm} \\
\mathrm{M}_{\mathrm{S}}: 55.9 \mathrm{emu} \mathrm{g}^{-1} .\end{array}$ & $\begin{array}{c}20 \% \text { decreased activity over } \\
\text { three } 72 \text { h cycles }\end{array}$ & $\begin{array}{l}\text { Valenzuela et al. } \\
\qquad(2014) \text { [30] }\end{array}$ \\
\hline $\begin{array}{l}\text { Recombinant } \\
\text { cellulases from } \\
\text { Themotoga maritima }\end{array}$ & $\begin{array}{l}\text { Thiol-functionalized } \\
\mathrm{Fe}_{3} \mathrm{O}_{4} \mathrm{NPs} \text { and } \\
\text { gold-doped } \\
\text { nanoparticles }\end{array}$ & $\begin{array}{c}27 \mathrm{~nm} \\
\mathrm{M}_{\mathrm{S}}: 33.3 \mathrm{emu} \mathrm{g}^{-1}\end{array}$ & $\begin{array}{c}40 \% \text { decreased activity over } \\
\text { three cycles }\end{array}$ & $\begin{array}{c}\text { Cho et al. (2012) } \\
\text { [18] }\end{array}$ \\
\hline $\begin{array}{l}\text { Cellulases from } T \text {. } \\
\text { reesei }\end{array}$ & $\begin{array}{l}\text { Amine-functionalized } \\
\qquad \mathrm{Fe}_{3} \mathrm{O}_{4} \mathrm{NPs}\end{array}$ & $\begin{array}{l}23.5 \mathrm{~nm} \\
\mathrm{M}_{\mathrm{S}}: \mathrm{ND}\end{array}$ & $\begin{array}{l}\text { 23.5\% decreased activity over } \\
\text { six } 24 \mathrm{~h} \text { cycles. } \\
\text { Protein loading: } 0.053 \mathrm{mg} \mathrm{g}^{-1}\end{array}$ & $\begin{array}{l}\text { Alahakoon et al. } \\
\text { 2013 [31] }\end{array}$ \\
\hline $\begin{array}{l}\text { Cellulases from } T \text {. } \\
\text { reesei }\end{array}$ & Zinc-doped $\mathrm{Fe}_{3} \mathrm{O}_{4} \mathrm{NPs}$ & $\begin{array}{c}40 \mathrm{~nm} \\
\mathrm{M}_{\mathrm{S}}: \mathrm{ND}\end{array}$ & $\begin{array}{l}\text { No loss of activity after } 45 \\
\text { days at } 4{ }^{\circ} \mathrm{C} / 50 \% \text { decreased } \\
\text { activity over five } 48 \text { h cycles }\end{array}$ & $\begin{array}{l}\text { Abraham et al. } \\
\text { (2014) [12] }\end{array}$ \\
\hline $\begin{array}{l}\text { Cellulases from } \\
\text { Humicola insolens }\end{array}$ & $\begin{array}{l}\text { Amine-functionalized } \\
\qquad \mathrm{Fe}_{3} \mathrm{O}_{4} \mathrm{NPs}\end{array}$ & $\begin{array}{c}\text { Size: ND } \\
\text { Ms: }_{32-39 \text { emu g }^{-1}}\end{array}$ & $\begin{array}{l}\text { 23\% decreased activity by } \\
\text { adsorption on } \\
\text { AEAPTMES-condensed MNP. } \\
\text { Protein loading: } 112 \mathrm{mg} \mathrm{g}^{-1}\end{array}$ & $\begin{array}{c}\text { Zhang et al. (2014) } \\
\text { [33] }\end{array}$ \\
\hline $\begin{array}{c}\text { Cellulases } \\
\text { (Novozymes) }\end{array}$ & $\begin{array}{l}\text { Amine-functionalized } \\
\qquad \mathrm{Fe}_{3} \mathrm{O}_{4} \mathrm{NPs}\end{array}$ & $\begin{array}{c}\text { Size: ND } \\
\mathrm{M}_{\mathrm{S}}: 54.7 \mathrm{emu} \mathrm{g}^{-1}\end{array}$ & $\begin{array}{l}\text { 35\% decreased activity over } \\
\qquad 100 \mathrm{~h} \\
\text { Protein loading: } 161 \mathrm{mg} \mathrm{g}^{-1}\end{array}$ & $\begin{array}{c}\text { Zhang et al. (2016) } \\
\text { [19] }\end{array}$ \\
\hline $\begin{array}{l}\text { Cellulases from } T \text {. } \\
\text { longibrachiatum }\end{array}$ & $\begin{array}{l}\text { Amine-functionalized } \\
\qquad \mathrm{Fe}_{3} \mathrm{O}_{4} \mathrm{NPs}\end{array}$ & $\begin{array}{c}90-100 \mathrm{~nm} \\
\mathrm{MS}_{\mathrm{S}}: 400 \mathrm{emu} \mathrm{g}^{-1}\end{array}$ & $\begin{array}{l}40 \% \text { decreased activity over } 15 \\
\text { h of hydrolysis at } 30{ }^{\circ} \mathrm{C} \text { using } \\
\text { pretreated Sesbania aculeate }\end{array}$ & $\begin{array}{c}\text { Baskar et al. (2016) } \\
\text { [34] }\end{array}$ \\
\hline $\begin{array}{l}\text { Cellulases from } T \text {. } \\
\text { reesei }\end{array}$ & $\begin{array}{l}\text { Amine-functionalized } \\
\mathrm{CoFe}_{2} \mathrm{O}_{4} \mathrm{NPs}\end{array}$ & $\begin{array}{c}8 \mathrm{~nm} \\
\mathrm{M}_{\mathrm{S}}: 46.01 \mathrm{emu} \mathrm{g}^{-1}\end{array}$ & $\begin{array}{l}36 \% \text { decreased activity after six } \\
\text { cycles of cellulose hydrolysis. }\end{array}$ & $\begin{array}{l}\text { Bohara et al. (2015) } \\
\text { [20] }\end{array}$ \\
\hline $\begin{array}{l}\text { Cellulases from } T \text {. } \\
\text { reesei }\end{array}$ & $\begin{array}{l}\text { Amine-functionalized } \\
\qquad \mathrm{Fe}_{3} \mathrm{O}_{4} \mathrm{NPs}\end{array}$ & $60 \mathrm{~nm}$ & $\begin{array}{l}62 \% \text { decreased activity over } \\
\text { four } 24 \mathrm{~h} \text { cycles } \\
\text { Protein loading: } 176 \mathrm{mg} \mathrm{g}^{-1}\end{array}$ & Jia et al. (2017) [35] \\
\hline $\begin{array}{l}\text { Cellulases from } A \text {. } \\
\text { niger }\end{array}$ & $\begin{array}{l}\text { Amine-functionalized } \\
\qquad \mathrm{Fe}_{3} \mathrm{O}_{4} \mathrm{NPs}\end{array}$ & $\begin{array}{c}\text { Size: ND } \\
\mathrm{M}_{\mathrm{S}}: 39.8 \mathrm{emu} \mathrm{g}^{-1}\end{array}$ & $\begin{array}{c}40 \% \text { decreased activity over six } \\
\text { cycles of hydrolysis for lipids } \\
\text { extraction }\end{array}$ & $\begin{array}{l}\text { Chen et al. (2018) } \\
\text { [36] }\end{array}$ \\
\hline $\begin{array}{l}\text { Cellulases from } A \text {. } \\
\text { niger }\end{array}$ & $\begin{array}{l}\text { Amine-functionalized } \\
\text { magnetic halloysite } \\
\text { nanotubes }\end{array}$ & $\begin{array}{c}\text { Size: ND } \\
\mathrm{M}_{\mathrm{S}}: 32.54 \mathrm{emu} \mathrm{g}^{-1}\end{array}$ & $\begin{array}{l}\text { 31.8\% decreased activity after } \\
\text { seven } 48 \text { h cycles } \\
\text { Cellulase activity yield } 93.5 \% \\
\text { Protein loading: } 80.48 \% .\end{array}$ & $\begin{array}{l}\text { Sillu \& Agnihotri } \\
\text { (2020) [37] }\end{array}$ \\
\hline
\end{tabular}

Other studies explored polyacrylic acid (PAA) brush scaffolds to immobilize cellulases from $T$. reesei, while one preparation used 2D graphene magnetized nanoplatelets as nanocarriers [40] and another a magnetite NP core [41]. The polyacrylic acid-modified graphene scaffolds were embedded in a suspension with maghemite-magnetite nanoparticles (layer-by-layer assembly) prior to enzymatic immobilization with EDC. The MNPs core method was coated with silica and functionalized with epoxy groups to graft the polymeric brushes, and the cellulases were adsorbed by PAA at $\mathrm{pH} 4.0$ overnight. These differential methods showed low practical application since enzymatic stability did not improve compared to the free enzyme. There was a protein loss for the adsorbed cellulases by the $\mathrm{pH}$-triggered release of about $50 \%$ after each cycle. Another polymeric matrix created by Lima et al. [28] was based on MNPs encapsulated by poly(methyl methacrylate)- 
PMMA using a miniemulsion method and was used to bind Cellusoft CR enzymes. The encapsulated nanomaterial presented a $\mathrm{M}_{\mathrm{S}}$ of $44.6 \mathrm{emu}^{-1}$. In contrast, the immobilized enzymes showed similar stability to the free enzymes but could be recycled during eight hydrolysis cycles, and enzyme activities dropped to $31 \%$.

Chitosan-coated MNPs are a promising approach to obtain a nanosupport for enzyme immobilization. Through a simple addition of chitosan of low molecular weight in a $1 \%$ acetic acid solution to the MNPs [42]. A similar nano-support was prepared by Sanchéz-Ramírez et al. [43] to immobilize cellulases from T. ressei that were used in the hydrolysis of pretreated agave. The result was improved thermal and storage stability, while the enzymatic activity was decreased to $50 \%$ after four $20 \mathrm{~h}$ cycles of agave hydrolysis. However, only $37 \%$ of cellulase activity was retained by the support after immobilization using GTA cross-linking.

A recent study reported chitosan-coated $\gamma-\mathrm{Fe}_{2} \mathrm{O}_{3}$ porous biochar prepared by a thermal conversion method. After activation with glutaraldehyde, cellulases from Humicola insolens were added, resulting in a protein efficiency of $80.5 \mathrm{mg} \mathrm{g}^{-1}$ support after $12 \mathrm{~h}$. No improvements in the stability were observed, but the activity was $73 \%$ and the reduction in glucose productivity was $24 \%$ after five $48 \mathrm{~h}$ cycles [44], higher values than those obtained in previous studies with chitosan coating. However, the saturation magnetization of this porous support was low $\left(0.67 \mathrm{emu} \mathrm{g}^{-1}\right)$, which is a notable disadvantage for its practical application.

A recent strategy is a metal-based hybrid porous material known as metal organic framework (MOF). Although MOFs are micro-scale, their porous structure can be condensed with functionalized MNPs and present large surface-to-volume ratios [38]. Qi and co-workers [45] carried out a pioneering study using the MOF UIO-66- $\mathrm{NH}_{2}$ to functionalize poly(sodium 4-styrenesulfonate)-condensed MNPs. Furthermore, the immobilized cellulases showed better tolerance to the presence of formic acid and vanillin, lignin-derived inhibitors, and changes in $\mathrm{pH}$ and temperature than free enzymes. Graphene oxides and MOF are nanomaterials that have recently been explored as carriers for enzyme immobilization. Graphene oxide is a carbon-based lattice presented as a two-dimensional single or double layer mimicking a honeycomb. Its attractive nanostructure has attracted much interest because of the large surface area available for functionalization, and the high conductivity obtained by exfoliation and subsequently oxidation [38]. Han et al. [21] described a novel carrier for cellulase immobilization consisting of magnetic graphene oxide $\left(\mathrm{GO} @ \mathrm{Fe}_{3} \mathrm{O}_{4}\right)$ coated with a dendritic polymer amine-functionalized (GO@Fe3O4@4armPEG-NH${ }_{2}$ ). During immobilization, the parameters investigated were cellulase dosage, time, and temperature. Therefore, enzymatic immobilization resulted in a retained activity of $93.5 \mathrm{U} \mathrm{mg}^{-1}$. After one month of storage, the enzymatic activity was $50 \%$, while tolerance to changes of $\mathrm{pH}$ or temperature of immobilized cellulases was improved. Although a high protein loading capacity characterized this technique $\left(575 \mathrm{mg} \mathrm{g}^{-1}\right)$, the resulting hybrid material presented low magnetization and a greater tendency to aggregation due to $\pi-\pi$ stacking attraction [38], which limits its operational and colloidal stability for applications in biocatalysis.

In conclusion, graphene-derived nanomaterials are not yet suitable for long-term applications of immobilized cellulase. At the same time, MOF or grafting polymer brushes on MNPs involves high manufacturing costs and probably toxicity in an aqueous medium. On the other hand, chitosan-coated MNPs present good magnetization and are a better choice regarding environmental and economic effects, but lack mechanical stability. In this way, amine-silanes and biopolymers have shown better results for long-term saccharification; however, their recyclability for industrial applications of bioreactors must be managed according to the long-term colloidal stability of nanomaterials. A summary of polymer-coated magnetic materials for cellulose immobilization is presented in Table 2. 
Table 2. Selected procedures of functionalized MNPs using cellulose-degrading enzymes and polymers.

\begin{tabular}{|c|c|c|c|c|}
\hline Enzyme & Magnetic Carrier & Carrier Size/M $\mathbf{M}_{\mathrm{S}}$ & Results & Reference \\
\hline Cellulases from $T$. viride & $\mathrm{PVA} / \mathrm{Fe}_{2} \mathrm{O}_{3} \mathrm{NPs}$ & $\begin{array}{l}270 \mathrm{~nm} \\
\mathrm{M}_{\mathrm{S}}: \mathrm{ND}\end{array}$ & $\begin{array}{l}60 \% \text { decreased activity over } \\
\text { four } 6 \text { h cycles }\end{array}$ & $\begin{array}{l}\text { Liao et al. (2010) } \\
\text { [39] }\end{array}$ \\
\hline Cellulases from $T$. reesei & $\begin{array}{l}\text { 2D graphene with } \\
\text { maghemite-magnetite } \\
\text { and PAA brushes }\end{array}$ & ND & $\begin{array}{c}38 \% \text { and } 45 \% \text { decreased } \\
\text { activity over three and four } 1 \mathrm{~h} \\
\text { cycles, respectively. }\end{array}$ & $\begin{array}{l}\text { Gokhale et al. } \\
\text { (2013) [40] }\end{array}$ \\
\hline Cellulases from $T$. reesei & $\begin{array}{l}\text { Silica-coated } \mathrm{Fe}_{3} \mathrm{O}_{4} \mathrm{NPs} \\
\text { grafted with PAA } \\
\text { brushes }\end{array}$ & $\begin{array}{l}200 \mathrm{~nm} \\
\mathrm{M}_{\mathrm{S}}: \mathrm{ND}\end{array}$ & $\begin{array}{l}\text { About } 50 \% \text { of protein release } \\
\text { by pH-triggered over one cycle }\end{array}$ & $\begin{array}{c}\text { Kudina et al. (2014) } \\
\text { [41] }\end{array}$ \\
\hline Cellusoft CR & $\begin{array}{l}\text { Poly(methylmethacrylate)- } \\
\text { encapsulated } \\
\mathrm{Fe}_{3} \mathrm{O}_{4} \mathrm{NPs}\end{array}$ & $\begin{array}{c}150 \mathrm{~nm} \\
\mathrm{M}_{\mathrm{S}}: 44.6 \mathrm{emu} \mathrm{g}^{-1}\end{array}$ & $\begin{array}{l}31 \% \text { decreased activity over } \\
\text { eight cycles }\end{array}$ & $\begin{array}{l}\text { Lima et al. (2016) } \\
\text { [28] }\end{array}$ \\
\hline $\begin{array}{l}\text { Cellulases from } \\
\text { Humicola insolens }\end{array}$ & $\begin{array}{l}\text { Chitosan-coated } \\
\mathrm{Fe}_{3} \mathrm{O}_{4} \mathrm{NPs}\end{array}$ & $\begin{array}{c}18 \mathrm{~nm} \\
\mathrm{M}_{\mathrm{S}}: 46.6 \mathrm{emu} \mathrm{g}^{-1}\end{array}$ & $\begin{array}{l}50 \% \text { decreased activity over } \\
\text { five } 48 \text { h cycles } \\
\text { Protein loading: } 112.3 \mathrm{mg} . \mathrm{g}^{-1}\end{array}$ & $\begin{array}{l}\text { Zang et al. (2014) } \\
\text { [44] }\end{array}$ \\
\hline Cellulases from T. reesei & $\begin{array}{l}\text { Chitosan-coated } \\
\mathrm{Fe}_{3} \mathrm{O}_{4} \mathrm{NPs}\end{array}$ & $\begin{array}{c}10 \mathrm{~nm} \\
\mathrm{M}_{\mathrm{S}}: 45.09 \mathrm{emu} \mathrm{g}^{1}\end{array}$ & $\begin{array}{l}50 \% \text { decreased activity over } \\
\text { five } 20 \mathrm{~h} \text { cycles }\end{array}$ & $\begin{array}{l}\text { Sánchez-Ramírez } \\
\text { et al. (2017) [43] }\end{array}$ \\
\hline $\begin{array}{l}\text { Cellulases from } \\
\text { Humicola insolens }\end{array}$ & $\begin{array}{c}\text { Chitosan-coated } \\
\gamma-\mathrm{Fe}_{2} \mathrm{O}_{3} \text { magnetized } \\
\text { porous biochar }\end{array}$ & $\begin{array}{c}\text { Pore: } 3.8 \mathrm{~nm} \\
\mathrm{M}_{\mathrm{S}}: 0.67 \mathrm{emu} \mathrm{g}^{-1}\end{array}$ & $\begin{array}{l}24 \% \text { of decreased glucose yield } \\
\text { over five } 48 \text { h cycles. } \\
\text { Protein loading: } 80.5 \mathrm{mg} \mathrm{g}^{-1}\end{array}$ & $\begin{array}{c}\text { Mo \& Qiu, (2020) } \\
\text { [44] }\end{array}$ \\
\hline $\begin{array}{l}\text { Cellulases from SunSon } \\
\text { group }\end{array}$ & $\begin{array}{c}\text { Poly (sodium } \\
\text { 4-styrenesulfonate)- } \\
\text { modified } \mathrm{Fe}_{3} \mathrm{O}_{4} \mathrm{NPs} \\
\text { and UIO-66- } \mathrm{NH}_{2} \mathrm{MOF}\end{array}$ & $174.5 \mathrm{~nm}$ & $\begin{array}{l}30 \% \text { decreased activity over } \\
\text { five } 24 \mathrm{~h} \text { cycles of MCC } \\
\text { hydrolysis. Protein loading: } \\
126.2 \mathrm{mg} \mathrm{g}^{-1}\end{array}$ & Qi et al. (2018) [45] \\
\hline Cellulases from $A$. niger & $\begin{array}{c}\text { Graphene oxide } \\
\left(\mathrm{GO} @ \mathrm{Fe}_{3} \mathrm{O}_{4}\right) \text { coated by } \\
\text { 4arm-PEG-NH } \mathrm{N}_{2}(10 \mathrm{~K})\end{array}$ & $\begin{array}{c}\text { Size: ND } \\
\mathrm{M}_{\mathrm{S}}: 15.8 \mathrm{emu} \mathrm{g}^{-1}\end{array}$ & $\begin{array}{l}55 \% \text { decreased activity over } \\
\text { eight } 2.5 \text { h cycles of a paper } \\
\text { filter. } \\
\text { Protein loading: } 570 \mathrm{mg} \mathrm{g}^{-1}\end{array}$ & $\begin{array}{l}\text { Han et al. (2018) } \\
\text { [21] }\end{array}$ \\
\hline
\end{tabular}

\subsection{Immobilization and Co-Immobilization of Hemicellulose-Degrading Enzymes}

Hemicellulose is a branched heterogenous polysaccharide consisting of hexose, pentose, and uronic acid monomers. However, a common feature in hardwood is a xylan main chain with 500 to 3000 monomers or pectin-like galactoglucomannan in softwood. The xylan bioconversion to sugar and sugar-acid units is performed frequently by $\beta$ 1,4-xylanase (endoxylanase) and $\beta-1,4-x y l o s i d a s e$, which hydrolyze $\beta-1,4-$ linked xylose backbone and xylooligosaccharides/xylobiose non-reducing end to release xylose. Although hemicellulose is less recalcitrant than cellulose because of its branched structure, it is wrapped with the cellulose microfibrils and cross-linked with lignin, creating a triad matrix. Hence, pretreated biomass usually contains xylooligomers that demand a co-immobilization strategy for their bioconversion. On the other hand, lignocellulosic biomass without pretreatment requires several debranching enzymes for efficient hydrolysis, such as $\beta$-mannanases, $\alpha$-arabinofuranosidase, acetylxylan esterase, $\alpha$-galactosidases, $\alpha$-arabinosidase, $\alpha$-glucuronidase, $\beta$-mannosidases, and ferulic acid esterases, among others [46]. The strategies applied to biodegrade hemicellulose components by enzyme-MNP systems are described below. Bhattacharya and Pletschke [47] introduced the concept of magnetic CLEAs in co-immobilization of hemicellulases from a strain of Bacillus gelatini, after precipitation with $80 \%$ ammonium sulfate at $4{ }^{\circ} \mathrm{C}$. Amine-functionalized MNPs were employed for this purpose, and the effect of $\mathrm{CaCl}_{2}$ addition before the cross-linking step was evaluated to compare the results for retained specific activities from the crude extract. A higher retained specific activity resulted in xylanase and $\beta$-xylosidase $\left(>4 \mathrm{U} \mathrm{mg}^{-1}\right)$, and to a lesser extent $\alpha$-arabinofuranosidase, $\beta$-galactosidase, and esterase $\left(\leq 2 \mathrm{U} \mathrm{mg}^{-1}\right)$. Although $\mathrm{Ca}^{2+}$ did not influence the retained activity after the formation of CLEAs, the 
binding to protein residues was associated with a thermo stabilizing effect. It occurred mainly for xylanase at $50{ }^{\circ} \mathrm{C}$ due to its $\mathrm{Ca}^{2+}$-binding domain located in the carbohydratebinding module. The evaluation of hydrolytic efficiency over pretreated sugarcane bagasse resulted in enhanced sugar release for the magnetic CLEAs prepared by adding $\mathrm{Ca}^{2+}$. This resulted in better performance during reusability tests. Once its reuse was possible during a third $72 \mathrm{~h}$ cycle ( $33.8 \%$ and $78 \%$ of declined activity on the second and third cycles), the CLEAs prepared without adding $\mathrm{Ca}^{2+}$ resulted in $60 \%$ decreased activity after the second cycle and no activity after the third cycle.

Another investigation conducted by Soozanipour et al. [48] involved the covalent attachment of xylanase with amine-functionalized MNPs that counted on the activation by cyanuric chloride. A subsequent enzymatic immobilization step was carried out on the 1,3,5-triazine functionalized MNPs for $16 \mathrm{~h}$ at room temperature. Reduced activity of 35\% was reported after nine cycles of hydrolysis. Moreover, xylanases immobilized by this method showed significant improvements in thermal stability, $\mathrm{pH}$ stability, and storage stability.

A different approach consisted of the synthesis of a hyperbranched polyglycerol grafted on silica coated MNPs. Activation of this support, developed by Landarani-Isfahani et al. [49], included functionalization with toluene 2,4-diisocyanate (TDI) and conjugation by adding citric acid. Immobilized xylanase showed better stability under $\mathrm{pH}$ changes than free xylanase. Practical use of this method was demonstrated by a retained activity of $66 \%$ after 10 cycles of hydrolysis and $74 \%$ of initial activity after 100 days of storage at $4{ }^{\circ} \mathrm{C}$.

Co-immobilization using cellulases and xylanases has been used to enhance efficiency during pulp hydrolysis to fermentable sugars. A study by Permez et al. [50] developed a coimmobilization technique for pectinase, xylanase and cellulase using amine-functionalized MNPs. The enzyme complex known as Pectinex 3XL was immediately incubated overnight at $4{ }^{\circ} \mathrm{C}$ and exhibited the following activities after immobilization: $87 \%$ pectinase, $69 \%$ xylanase and 58\% cellulase. Furthermore, the thermal stability was improved in the immobilized state, while the activity was retained and even after six cycles of hydrolysis was higher than $80 \%$.

Recombinant xylanase from Bacillus sp. and cellulases from Rhodothermus marinus were employed in co-immobilization on MNPs activated by 1\% GTA solution overnight. Immobilization efficiency obtained by this technique was $91.75 \%$ for xylanase and $45.32 \%$ for endoglucanase, while after 45 days of storage at $4{ }^{\circ} \mathrm{C}$ residual activities were 85 and $80 \%$, respectively [51]. A notably stable co-immobilization approach was described by Periyasamy et al. [52] Crosslinking of $97 \%$ of proteins by GTA addition was employed. The procedure to obtain the carrier consisted of a two-step condensation of MNPs with TEOS and then with APTES to finally co-anchor cellulases, xylanase and $\beta-1.3$-glucanase by GTA addition at $30{ }^{\circ} \mathrm{C}$. The following retained activities were obtained: $98.1 \%$ xylanase, $98.3 \%$ cellulase, and $97.3 \% \beta-1.3$-glucanase. The co-immobilized enzymes by this method presented enhanced thermal stability compared to free enzymes, also notorious for storage stability, with more than $95 \%$ of activity retained after 120 days while free enzyme activity decreased by approximately $30 \%$. A practical application showed that the overall hydrolysis yield of sugarcane bagasse pulp and eucalyptus pulp increased by about $10-15 \%$ using this co-immobilization technique compared to free enzymes.

An efficient magnetic system for saccharification developed by Hwangbo et al. [53] involved producing five recombinant enzymes and their subsequent co-immobilization: $\beta$-glucosidase, endoglucanase and endoxylanase from Bacillus subtilis. At the same time, exoglucanase and xylosidase were designed from genes of $A$. fumigatus. After protein expression, the recombinant crude enzymes were precipitated using $80 \%$ ammonium sulfate solution at $4{ }^{\circ} \mathrm{C}$ for $1 \mathrm{~h}$, and finally prepared magnetic CLEAs, $0.8 \%$ of GTA solution was added for $2 \mathrm{~h}$ in the presence of MNPs. Bioconversion by this technique was carried out with pretreated corn husks, and the yield of reducing sugars was higher for CLEAs using these recombinant enzymes than both free commercial enzymes and free recombinant enzymes. Finally, this magnetic system of recombinant enzymes presented an excellent yield of reducing sugars during three cycles of $48 \mathrm{~h}$; however, in the fourth cycle, the yield 
decreased considerably due to possible protein leachates (the retained enzymatic activities were not determined).

A magnetic nanocomposite was obtained by adding graphene oxide during MNPs synthesis (GO-MNPs) in the research conducted by Mehnati-Najafabadi et al. [54]. The resulting nanomaterial was functionalized with polyethylene glycol bis-amine (PEGA) and activated by EDC coupling. Then xylanase incubation for $14 \mathrm{~h}$ in the nanocomposite activated by cyanuric chloride resulted in a protein loading of $211 \mathrm{mg} \mathrm{g}^{-1}$. This technique improved the thermal stability and tolerance of xylanase to $\mathrm{pH}$ changes. A similar study described a method for direct functionalization of GO-MNPs by EDC and NHS coupling reaction. A subsequent step was the co-immobilization of cellulases and xylanases for $12 \mathrm{~h}$. Although the capacity of this nanosupport to bind protein was low, approximately $50 \mathrm{mg} \mathrm{g}^{-1}$, the total obtained yield of $96.5 \%$ is remarkable. The specific activities for each enzyme were higher than $90 \%$, except for endoglucanase, which reached $63 \%$, and xylanase, which showed the lowest value with $27 \%$. Even so, the reuse of these immobilized biocatalysts was possible for eight cycles with less than $25 \%$ activity reduction, except for xylanase, which lost about $30 \%$ of its activity. Furthermore, the hydrolysis of sugarcane bagasse pretreated with xylose was maintained with a $78 \%$ yield until the fifth cycle, but the glucose yield was lowered by $34 \%$ after five cycles [55]. In this context, immobilized xylanase in activated MNPs using EDC as a coupling agent and grafting to GO is a promising route for xylan saccharification and recyclability of its bioactivity.

A recent study reported a biobased nanomaterial of cellulose nanocrystals (CNCs) functionalized with MNPs and dopamine, which resulted in a nanocarrier with amine

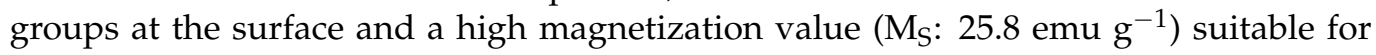
enzyme immobilization. First, sugar beet pulp powder was subjected to enzymatic treatment for three days and acid hydrolysis for $4 \mathrm{~h}$. After purification of the released CNCs, MNPs were synthesized in a CNCs solution for $1 \mathrm{~h}$, and finally the functionalization with dopamine occurred for $2 \mathrm{~h}$. Enzyme immobilization by dopamine has been considered a conjugation where dopamine catechol and amine groups conjugate with the carboxylate and other attractive groups of enzymes. As a result, a better synergistic effect of conjugated xylanases was achieved at molar ratios of 80:20 and 60:40 for conjugated cellulases, which corresponded to retained activities higher than $90 \%$. Improved thermal stability of cellulases was observed at $90^{\circ} \mathrm{C}$, while tolerance to $\mathrm{pH}$ changes was pronounced for the immobilized xylanases. However, about $4-25 \%$ of enzymes were leached after washing with buffer solution, especially xylanases at high temperatures [56].

Hemicellulose components account for up to one-third of the biomass composition and are found as a link between cellulose microfibrils. Therefore, biomass conversion in a biorefinery needs to effectively address the hemicellulose contents. The main approaches discussed in this section for hemicellulose components biodegradation by enzymes-functionalized magnetic carriers are summarized in Table 3.

\subsection{Immobilization of Lignin-Degrading Enzymes}

Lignin is a highly branched polyaromatic macromolecule resulting from radical condensation of guaiacyl, syringyl, and p-hydroxyphenyl monomers crosslinked by three kinds of bonds: $\beta$-aryl ether linkages, biphenyl, and heterocyclic linkages. Lignin is also exclusive according to epigenetic factors for each plant. It has high recalcitrance to hydrolysis due to its complex branched structure so that its degradation requires several catalytic pathways and interventions by fungi or bacteria [57]. However, mainly three oxidative enzymes have been explored to degrade phenolic compounds originated by partial degradation of biomass in alkaline or acidic conditions. For instance, laccase is a blue copper oxidase widely studied and produced by higher plants, insects, bacteria, and fungi. Besides manganese peroxidase and lignin peroxidase, two heme glycoproteins mediated by hydrogen peroxide that are capable of oxidizing phenolic and non-phenolic lignin compounds were also described. White-rot fungi are well known for the secretion of ligninolytic enzymes, such as oxidative enzymes and cellulases and hemicellulases able to 
degrade organic compounds from wood through a natural recycling process. Bacteria are less explored for oxidative enzyme production, although they also produce peroxidases, laccases, and mainly dye-decolorizing peroxidases $[58,59]$.

Table 3. Selected procedures of magnetic conversions using hemicellulose-degrading enzymes.

\begin{tabular}{|c|c|c|c|c|}
\hline Enzyme & Magnetic Carrier & Carrier Size/M $\mathbf{M}$ & Results & Reference \\
\hline $\begin{array}{l}\text { Xylanases from Bacillus } \\
\text { gelatini ABBP-1 }\end{array}$ & $\begin{array}{c}\text { CLEAs with } \\
\text { amine-functionalized } \\
\mathrm{Fe}_{3} \mathrm{O}_{4} \mathrm{NPs},\end{array}$ & ND & $\begin{array}{l}78 \% \text { decreased activity } \\
\text { after three } 72 \mathrm{~h} \text { cycles of } \\
\text { pretreated sugarcane } \\
\text { bagasse }\end{array}$ & $\begin{array}{c}\text { Bhattacharya \& } \\
\text { Pletschke (2014) [47] }\end{array}$ \\
\hline $\begin{array}{l}\text { Xylanase from } \\
\text { Thermomyces } \\
\text { lanuginosus }\end{array}$ & $\begin{array}{c}\text { Amine- } \\
\text { functionalizedFe }{ }_{3} \mathrm{O}_{4} \mathrm{NPs}\end{array}$ & $\begin{array}{c}9 \mathrm{~nm} \\
\mathrm{M}_{\mathrm{S}}: 46.56 \mathrm{emu} \mathrm{g}^{-1}\end{array}$ & $\begin{array}{l}80 \% \text { of activity remained } \\
\text { after } 3 \text { months at } 4{ }^{\circ} \mathrm{C} / 35 \% \\
\text { decreased activity after } \\
\text { nine cycles. } \\
\text { Protein loading: } 280 \mathrm{mg} \\
\mathrm{g}^{-1}\end{array}$ & $\begin{array}{l}\text { Soozanipour et al. } \\
\text { (2015) [48] }\end{array}$ \\
\hline $\begin{array}{l}\text { Xylanases, pectinases } \\
\text { and cellulases from } \\
\text { Pectinex 3XL }\end{array}$ & $\begin{array}{l}\text { Amine-functionalized } \\
\mathrm{Fe}_{3} \mathrm{O}_{4} \mathrm{NPs}\end{array}$ & $\begin{array}{c}63 \mathrm{~nm} \\
\mathrm{M}_{\mathrm{S}}: \mathrm{ND}\end{array}$ & $\begin{array}{c}20 \% \text { of decreased activities } \\
\text { after six cycles of } \\
\text { hydrolysis }\end{array}$ & $\begin{array}{l}\text { Permez et al. (2017) } \\
\text { [50] }\end{array}$ \\
\hline $\begin{array}{l}\text { Recombinant xylanases } \\
\text { from Bacillus sp. and } \\
\text { cellulases from } \\
\text { Rhodothermus marinus }\end{array}$ & $\mathrm{Fe}_{3} \mathrm{O}_{4} \mathrm{NPs}$ & ND & $\begin{array}{l}30 \% \text { decreased activity } \\
\text { after eight } 12 \text { h cycles }\end{array}$ & $\begin{array}{c}\text { Kumar et al. (2018) } \\
\text { [51] }\end{array}$ \\
\hline $\begin{array}{l}\text { Xylanases, cellulases } \\
\text { and } \beta-1.3 \text {-gluconase } \\
\text { from T. citrinoviride }\end{array}$ & $\begin{array}{l}\text { Amine-functionalized } \\
\text { silica -coated } \mathrm{Fe}_{3} \mathrm{O}_{4} \mathrm{NPs}\end{array}$ & $\begin{array}{l}86.4 \mathrm{~nm} \\
\mathrm{M}_{\mathrm{S}}: \mathrm{ND}\end{array}$ & $\begin{array}{c}10-15 \% \text { increased } \\
\text { hydrolysis yield compared } \\
\text { to free enzymes }\end{array}$ & $\begin{array}{l}\text { Periyasamy et al. } \\
\text { (2018) [52] }\end{array}$ \\
\hline $\begin{array}{l}\text { Recombinant cellulases } \\
\text { and xylanases from } \\
\text { genes of Bacillus subtilis } \\
\text { and } A \text {. fumigatus }\end{array}$ & $\mathrm{Fe}_{3} \mathrm{O}_{4} \mathrm{NPs}-\mathrm{CLEAs}$ & ND & $\begin{array}{l}\text { Enhanced yield of reducing } \\
\text { sugars during three } 48 \mathrm{~h} \\
\text { cycles of pretreated corn } \\
\text { husks hydrolysis }\end{array}$ & $\begin{array}{l}\text { Hwangbo et al. (2019) } \\
\text { [53] }\end{array}$ \\
\hline $\begin{array}{c}\text { Xylanases and } \\
\text { cellulases from Cellic } \\
\text { CTec2 }\end{array}$ & $\begin{array}{l}\text { Graphene oxide } \\
\text { nanosheets with } \\
\mathrm{Fe}_{3} \mathrm{O}_{4} \mathrm{NPs}\end{array}$ & ND & $\begin{array}{l}78 \% \text { yield for xylose after } \\
\text { five } 24 \mathrm{~h} \text { cycles and } 34 \% \text { of } \\
\text { glucose from pretreated } \\
\text { bagasse. } \\
\text { Protein loading: } 50 \mathrm{mg} \mathrm{g}^{-1}\end{array}$ & $\begin{array}{l}\text { Paz-Cerdeno et al. } \\
\text { (2021) [55] }\end{array}$ \\
\hline $\begin{array}{l}\text { Xylanase from } T . \\
\text { lanuginosus }\end{array}$ & $\begin{array}{l}\text { Hyperbranched } \\
\text { polyglycerol-grafted on } \\
\text { silica-coated } \mathrm{Fe}_{3} \mathrm{O}_{4} \mathrm{NPs}\end{array}$ & $\begin{array}{c}\text { Size: ND } \\
\mathrm{M}_{\mathrm{S}}: 46.56 \mathrm{emu} \mathrm{g}^{-1}\end{array}$ & $\begin{array}{c}34 \% \text { decreased activity } \\
\text { after } 10 \text { cycles of hydrolysis } \\
\text { Protein loading: } 279 \mathrm{mg} \\
\mathrm{g}^{-1}\end{array}$ & $\begin{array}{l}\text { Landarani-Isfahani } \\
\text { et al. 2015 [49] }\end{array}$ \\
\hline $\begin{array}{l}\text { Xylanases from } T . \\
\text { lanuginosus }\end{array}$ & $\begin{array}{c}\text { Nanocomposite of } \\
\text { graphene } \\
\text { oxide-nanosheets } \\
\text { functionalized by PEG } \\
\text { with } \mathrm{Fe}_{3} \mathrm{O}_{4} \mathrm{NPs}\end{array}$ & $\begin{array}{c}30 \mathrm{~nm} \\
\mathrm{M}_{\mathrm{S}}: 34.5 \mathrm{emu} \mathrm{g}^{-1}\end{array}$ & $\begin{array}{l}50 \% \text { decreased activity } \\
\text { after four cycles of } \\
\text { hydrolysis } \\
\text { Protein loading: } 211 \mathrm{mg} \\
\mathrm{g}^{-1}\end{array}$ & $\begin{array}{l}\text { Mehnati-Najafabadi } \\
\text { et al. (2019) [54] }\end{array}$ \\
\hline $\begin{array}{l}\text { Three cellulases and } \\
\text { two xylanases purified } \\
\text { from rumen microbiota }\end{array}$ & $\begin{array}{l}\text { CNCs functionalized } \\
\text { with } \mathrm{Fe}_{3} \mathrm{O}_{4} \mathrm{NPs} \text { and } \\
\text { dopamine }\end{array}$ & $\begin{array}{l}\text { Diameter: } 25 \mathrm{~nm} \\
\text { Length: } 40-150 \mathrm{~nm} \\
\mathrm{M}_{\mathrm{S}}: 25.8 \mathrm{emu} \mathrm{g}^{-1}\end{array}$ & $\begin{array}{l}50 \% \text { decreased activity } \\
\text { after ten } 1 \text { h cycles }\end{array}$ & $\begin{array}{l}\text { Ariaeenejad et al. } \\
\quad 2021 \text { [56] }\end{array}$ \\
\hline
\end{tabular}

Biotechnological applications for microbial wood degradation have focused on biotreatment of wastewater from the textile industry, decolorizing industrial dyes, effluents from the pulp and paper industry, and oxidation of xenobiotics. Therefore, the study and development of strategies to stabilize and reuse these enzymes have been of great environmental importance to detoxify various compounds generated by industry, such as hydrocarbons, bisphenol, herbicides, pesticides, and polychlorinated substances. However, the topic to follow is the immobilization of these enzymes using MNPs for biomass processing once 
various lignin derivatives are released during biomass pretreatment, known as contaminants and enzyme inhibitors, such as phenolic compounds [59]. Also, bioremediation of effluents that are produced during biomass processing could be a promising approach once it allows the use of natural resources to yield biofuels and other bioproducts via green chemistry. In this way, recent advances presented for detoxifying effluents and lignin removal as sustainable biorefinery solutions are summarized in Table 4.

A first approach described by Hu et al. [60] aimed to catalyze the oxidation of guaiacol as a phenolic lignin model compound. The method consisted of the synthesis of aminefunctionalized and silica-coated MNPs and GTA mediated enzyme immobilization. Then a retained activity of $53.4 \%$ resulted by adding fungal laccase, and immobilized enzyme presented better thermal stability and tolerance to $\mathrm{pH}$ changes than free laccase. On the other hand, the reuse potential of this magnetic biocatalyst was not evaluated.

Enhanced accessibility to cellulose is another vital aspect of adding lignin-degrading enzymes during the green processing of biomass according to the yield of fermentable sugars. Amin et al. [61] demonstrated that laccase immobilized onto amine-functionalized mesoporous material with a magnetic core did not enhance olive pomace delignification. However, the addition of the ionic liquid 1-butyl-3-methylimidazolium hexafluorophosphate [Bmim, PF6] with the immobilized laccase produced a higher concentration of fermentable sugars than the treatment by ionic liquid or free enzyme. Furthermore, stability during storage and changes in temperature or $\mathrm{pH}$ were improved for the laccase immobilized by this method.

MNPs have been deliberately modified with $\mathrm{Cu}^{2+}$ once the laccase isozymes present copper induced metal affinity, so oxidative bioactivity was enhanced by copper adsorption. This was also evidenced by a comparison study between ferrite NPs and copper ferrite NPs, with the latter being the most suitable to laccase immobilization after aminefunctionalization and GTA-based crosslinking. First, optimization of the immobilization process resulted in a retained activity of $94.68 \%$ after $9 \mathrm{~h}$ of incubation. Higher lignin removal from Ipomoea carnea was obtained using immobilized laccase on functionalized copper ferrite NPs (43.3\%) compared to the free enzyme (38.2\%). Moreover, storage stability for 20 days at $4{ }^{\circ} \mathrm{C}$ and thermal and $\mathrm{pH}$ stabilities were improved for immobilized laccase using this method [15].

The environmental concern about the treatment of the effluents produced by biorefineries was addressed in detail by Vishnu et al. [62]. They evaluated the yields and products obtained through oxidation of several model phenolic compounds derived from lignin using laccase and peroxidase co-immobilized by adsorption on commercial functionalized magnetic silica microspheres. The designed biocatalysts were obtained using T. asperellum laccase and amine-functionalized MNPs at different incubation times. An immobilization efficiency of $64.7 \%$ with $6 \mathrm{~h}$ incubation was achieved. In addition, thermal and storage stabilities were improved by this immobilization technique, while the activity decreased $30 \%$ or $70 \%$ after four and eight 30 min cycles, respectively. Detoxification of phenolic compounds was studied using three model compounds, and the conversion yields by immobilized laccase for $48 \mathrm{~h}$ were: $37.89 \%$ for 2-phenoxy-1-phenylethanol, $79.63 \%$ for benzyl phenyl ether, and $99.53 \%$ for phenethyl benzene. The results were lower when compared to the ones obtained with the free enzyme treatment, and even the degradation routes were different for free and immobilized laccase, probably due to a different conformation of the activated benzene ring binding site [63]. 
Table 4. Selected procedures of magnetic conversions using lignin-degrading enzymes.

\begin{tabular}{|c|c|c|c|c|}
\hline Enzyme Binding & Magnetic Carrier & Carrier Size/M $\mathbf{M}_{\mathbf{S}}$ & Results & Reference \\
\hline Laccase from Aspergillus & $\begin{array}{l}\text { Amine- } \\
\text { functionalizedFe } \mathrm{O}_{4} \mathrm{NPs}\end{array}$ & ND & $\begin{array}{l}\text { Immobilization efficiency: } 53.4 \% \text { of its initial } \\
\text { activity }\end{array}$ & $\begin{array}{l}\text { Hu et al. } 2015 . \\
\text { [60] }\end{array}$ \\
\hline $\begin{array}{l}\text { Laccase from Trametes } \\
\text { versicolor }\end{array}$ & $\begin{array}{c}\text { Amine-functionalized } \\
\text { mesoporous material } \\
\text { with } \mathrm{Fe}_{3} \mathrm{O}_{4} \mathrm{NPs}\end{array}$ & ND & $\begin{array}{l}70 \% \text { of its initial activity after } 20 \text { days at } 25^{\circ} \mathrm{C} \text {. } \\
\text { Immobilization efficiency: } 84.4 \%\end{array}$ & Amin et al. 2018 \\
\hline $\begin{array}{l}\text { Laccase from Trametes } \\
\text { versicolor }\end{array}$ & $\begin{array}{l}\text { Amine-functionalized } \\
\mathrm{CuFe}_{2} \mathrm{O}_{4} \mathrm{NPs}\end{array}$ & $\begin{array}{c}50 \pm 20 \mathrm{~nm} \\
\mathrm{M}_{\mathrm{S}}: 9.85 \mathrm{emu} \mathrm{g}^{-1}\end{array}$ & $\begin{array}{l}43.2 \% \text { of lignin removal of Ipomoea carnea-70\% } \\
\text { of activity is retained after six } 1 \mathrm{~h} \text { cycles. } \\
\text { Protein binding capacity: } 118 \mathrm{mg} \mathrm{g}^{1}\end{array}$ & $\begin{array}{l}\text { Muthuvelu et al. } \\
2019 \text { [15] }\end{array}$ \\
\hline $\begin{array}{l}\text { Laccase from Trametes } \\
\text { versicolor }\end{array}$ & $\begin{array}{l}\text { Amine-functionalized } \\
\mathrm{Fe}_{3} \mathrm{O}_{4} \mathrm{NPs} \text {. }\end{array}$ & $182 \mathrm{~nm}$ & $\begin{array}{c}\text { Immobilization efficiency: } 64.7 \% \text {. } \\
\text { Activity decreased } 30 \% \text { and } 70 \% \text { after four and } \\
\text { eight } 30 \text { min cycles }\end{array}$ & $\begin{array}{l}\text { Chen et al. } 2020 \\
\text { [63] }\end{array}$ \\
\hline $\begin{array}{l}\text { Laccase from } \\
\text { Myrothecium verrucaria } \\
\text { 3H6 }\end{array}$ & $\begin{array}{l}\text { Polyethyleneimine (PEI)- } \\
\text { functionalized } \\
\mathrm{Fe}_{3} \mathrm{O}_{4} \mathrm{NPs} \\
\end{array}$ & ND & $\begin{array}{l}\text { Immobilization efficiency: } 87.4 \% \text { and } 85.3 \% \text { of } \\
\text { adsorbed protein-50\% of activity is retained } \\
\text { after six } 10 \text { min cycles. }\end{array}$ & $\begin{array}{l}\text { Gou et al. } 2020 \\
\text { [64] }\end{array}$ \\
\hline $\begin{array}{l}\text { Laccase from } \\
\text { Trichoderma asperellum }\end{array}$ & $\begin{array}{l}\text { Chitosan-functionalized } \\
\text { silica-coated } \mathrm{Fe}_{3} \mathrm{O}_{4} \mathrm{NPs}\end{array}$ & $\begin{array}{c}700 \mathrm{~nm} \\
\mathrm{M}_{\mathrm{S}}: 27.4 \mathrm{emu} \mathrm{g}^{-1}\end{array}$ & $\begin{array}{l}\text { Immobilization efficiency: } 92.4 \% \text {. } \\
\text { Activity decreased } 30 \% \text { after eight } 1 \mathrm{~h} \text { cycles. }\end{array}$ & $\begin{array}{l}\text { Shanmugam et al. } \\
2020[65]\end{array}$ \\
\hline
\end{tabular}

A strategy based on polymers was described in a delignification bioprocess of corn stover by adsorbed laccase. Laccase from Myrothecium verrucaria 3H6 was adsorbed on MNPs functionalized with polyethyleneimine (PEI) and GTA in the presence of $\mathrm{Cu}^{2+}$. Desorption by a $\mathrm{pH}$-trigger and a second bioprocess for cellulose hydrolysis of corn stover was done to avoid laccase inhibition. This new immobilization perspective described by Gou et al. [64] also studied various laccase concentrations and incubation times to improve immobilization efficiency by adsorption. The best results were obtained for $30 \mathrm{~min}$ of incubation with $2.5 \mathrm{mg} \mathrm{mL}^{-1}$ of protein that retained activity of $87.4 \%$ with $85.3 \%$ of adsorbed protein. Immobilization also improved the enzyme storage, $\mathrm{pH}$, and temperature stability. The treated corn stover biomass with immobilized enzyme presented $40.76 \%$ lignin degradation compared to $44.82 \%$ with free enzyme after $72 \mathrm{~h}$. However, cellulose hydrolysis by a second processing step increased by around $24 \%$.

A recent study by Shanmugam et al. [65] reported enhanced biohydrogen production from pretreated sweet sorghum stover using immobilized laccase for delignification. Enzymes' optimal parameters were determined using an experimental design for the EDCmediated crosslinking of laccase on silica-coated MNPs functionalized with chitosan. In this way, laccase immobilization efficiency was $92.4 \%$ and yield $91.2 \%$. Furthermore, the delignification of sweet sorghum stover was optimized, reaching a conversion of $84.4 \%$ at $60{ }^{\circ} \mathrm{C}$ and $\mathrm{pH} 4$ for $12 \mathrm{~h}$ using immobilized laccase. Finally, delignification improved biohydrogen production since the yield of fermentable sugars was increased using cellulases in a second stage.

The immobilization of laccases onto the magnetic supports has been a less explored technology compared to cellulases. Thus, the long-term applicability of nanomaterials for lignin derivatives biodegradation has not yet been conclusively demonstrated, except for the amine-functionalized mesoporous material. Although $\mathrm{M}_{\mathrm{S}}$ value is unknown for this strategy, the practical application of reusable immobilized laccases is a promising approach. The approaches based on lignin-degrading enzymes are summarized in Table 4.

\section{Key Factors of Magnetic Enzyme Immobilization}

Enzymes are incredibly efficient biocatalysts and are widely applied in different biotechnological areas. The enzyme cost, instability, and difficult recovery have hampered their industrial use. Magnetic nanomaterials have gained particular attention as enzyme carriers and support matrices for enzyme immobilization, owing to their large surface area, high mass-transference, easier separation step and enzyme recovery, and the possibility of enzyme reuse. Therefore, several studies investigating different magnetic materials, 
functionalization, and immobilization techniques for industrially relevant enzymes have been reported.

Crosslinking agents and immobilization conditions were seen to play important roles when the immobilization efficiency is in question. For example, the effect of weight ratio of protein to immobilization support and linker (e.g., GTA), concentration, and immobilization time are crucial parameters that define the remaining enzyme activity. GTA concentration is usually lower than $3 \%$, while incubation time depends on the enzyme of interest. It is essential to note that the optimization step is fundamental for immobilized enzyme efficiency, catalytic activity, stability, and recycling ability. The studies that previously determined the optimal immobilization parameters have usually shown better yields and efficiencies in enzyme immobilization [12,37,47,52,56,64,65].

Regarding the long-term stability of magnetic nano supports, it is essential to evaluate the stability of the colloidal dispersion of functionalized MNPs using techniques such as zeta potential and to determine hydrodynamic diameter using dynamic light scattering (DLS), since the development of more stable long-term nanomaterials will prevent agglomeration and subsequent loss of enzyme activity $[33,66]$. Changes in the conformational state of the enzyme also need to be investigated. A thorough characterization of the nanomaterial before and after its use should be considered, as should the surface-function relationship and binding sites in enzyme-functionalized nanoparticles. Some of the critical factors to keep in mind when dealing with magnetic enzyme immobilization are illustrated in Figure 2.

\section{Conclusions and Future Perspectives}

Biodegradation of lignocellulosic biomass is a green process preferred for industrial applications due to the high yields of fermentable sugars with low undesired by-products. Even so, some by-products released by lignin degradation might be a threat to the process and the environment. Therefore, the process has been transformed by the use of immobilized enzymes, such as laccases, and recent trends focus on valorization of the by-products, enabling improved cellulose hydrolysis or as a step in wastewater treatment to recover value-added chemicals.

Functionalized magnetic nanomaterials have offered several advantages in addition to their rapid collection when applying an external magnetic field and a possibility to recycle enzymes, which retain their bioactivity. Thus, immobilized enzymes also show a longer half-life during storage, better tolerance against inhibitors, and changes in temperature and $\mathrm{pH}$. Moreover, polymer-coated MNPs and grafting to graphene oxide are not yet suitable for long-term applications of immobilized cellulase, probably due to $\pi-\pi$ stacking interactions in the structure. On the other hand, immobilized xylanase onto MNPs by EDC coupling into graphene oxide has been a promising route that presented good recyclability results. At the same time, MOF or grafting polymer brushes on MNPs involves high manufacturing costs and possible toxicity issues. Although chitosan-coated MNPs present a good magnetization and have environmental and economic advantages, they still lack mechanical stability. In this way, amine-silanes and biopolymers are showing better results for long-term saccharification or lignin biodegradation. Nevertheless, their recyclability for industrial applications must be optimized according to long-term colloidal stability as nanocarriers.

Future research should be oriented towards the application and improvement of biobased materials as enzyme nanocarriers. Furthermore, co-immobilization of multienzymes such as laccase-xylanase and xylanase-cellulase can add a more versatile biorefinery toolbox and help to overcome the shortage of fuels. Lignin valorization using immobilized laccases also deserves more attention. The use of ionic liquids as auxiliary solvents to enhance the yields of reducing sugars is auspicious. On the other hand, the toxicity and possible consequences of the nanomaterials released into the environment need to be carefully addressed. 
Author Contributions: L.T. proposed the main idea and revised the review. S.F. reviewed the literature on the synthesis and characterization of magnetic nanoparticles and prepared the figures for the review. M.A.M. conducted a systematic investigation and wrote the manuscript. All authors have read and agreed to the published version of the manuscript.

Funding: This research received no external funding.

Institutional Review Board Statement: Not applicable.

Informed Consent Statement: Not applicable.

Data Availability Statement: Not applicable.

Acknowledgments: The authors acknowledge Coordenação de Aperfeiçoamento de Pessoal de Ensino Superior (CAPES) and Conselho Nacional de Pesquisa (CNPq).

Conflicts of Interest: The authors declare no conflict of interest.

\section{References}

1. Shuttleworth, P.S.; De Bruyn, M.; Parker, H.L.; Hunt, A.J.; Budarin, V.L.; Matharu, A.S.; Clark, J.H. Applications of nanoparticles in biomass conversion to chemicals and fuels. Green Chem. 2014, 16, 573-584. [CrossRef]

2. Jankowska, K.; Zdarta, J.; Grzywaczyk, A.; Kijeńska-Gawrońska, E.; Biadasz, A.; Jesionowski, T. Electrospun poly(methyl methacrylate)/polyaniline fibres as a support for laccase immobilisation and use in dye decolorisation. Environ. Res. 2020, 184, 109332. [CrossRef] [PubMed]

3. Zdarta, J.; Machałowski, T.; Degórska, O.; Bachosz, K.; Fursov, A.; Ehrlich, H.; Ivanenko, V.N.; Jesionowski, T. 3D Chitin scaffolds from the marine demosponge Aplysina archeri as a support for laccase immobilization and its use in the removal of pharmaceuticals. Biomolecules 2020, 10, 646. [CrossRef] [PubMed]

4. Misson, M.; Zhang, H.; Jin, B. Nanobiocatalyst advancements and bioprocessing applications. J. R. Soc. Interface 2015, 12, 1-20. [CrossRef] [PubMed]

5. Meryam Sardar, R.A. Enzyme immobilization: An overview on nanoparticles as an immobilization matrix. Biochem. Anal. Biochem. 2015, 4, 178-186. [CrossRef]

6. Roth, H.C.; Schwaminger, S.P.; Peng, F.; Berensmeier, S. Immobilization of cellulase on magnetic nanocarriers. Chem. Open 2016, 5, 183-187. [CrossRef] [PubMed]

7. Husain, Q. Nanomaterials immobilized cellulolytic enzymes and their industrial applications: A literature review. JSM Biochem. Mol. Biol. 2017, 4, 1029-1045. Available online: https://www.jscimedcentral.com/Biochemistry/biochemistry-4-1029.pdf (accessed on 20 September 2021).

8. Ghollobi, A.; Meshkat, Z.; Abnous, K.; Ghayour-Mobarhan, M.; Ramezani, M.; Shandiz, F.H.; Verma, K.D.; Darroudi, M. Biopolymer-mediate synthesis of $\mathrm{Fe} 3 \mathrm{O} 4$ nanoparticles and investigation of their in vitro cytotoxicity effects. J. Mol. Struct. 2017, 5, 594-599. [CrossRef]

9. Ali, A.; Shah, T.; Ullah, R.; Zhou, P.; Guo, M.; Ovais, M.; Tan, Z.; Rui, Y. Review on recent progress in magnetic nanoparticles: Synthesis, characterization, and diverse applications. Front. Chem. 2021, 9, 2296-2646. [CrossRef]

10. Indira, T.K.; Lakshmi, P.K. Magnetic nanoparticles-A review. Int. J. Pharm. Sci. Nanotech. 2010, 3, $1035-1042$.

11. Verma, M.L.; Chaudhary, R.; Tsuzuki, T.; Barrow, C.J.; Puri, M. Immobilization of $\beta$-glucosidase on a magnetic nanoparticle improves thermostability: Application in cellobiose hydrolysis. Bioresour. Technol. 2013, 135, 2-6. [CrossRef]

12. Abraham, R.E.; Verma, M.L.; Barrow, C.J.; Puri, M. Suitability of magnetic nanoparticle immobilised cellulases in enhancing enzymatic saccharification of pretreated hemp biomass. Biotechnol. Biofuels 2014, 7, 90-102. [CrossRef]

13. Verma, R.; Pathak, S.; Kumar, S.A.; Prawer, S.; Tomljenovic-Hanic, S. ZnO nanomaterials: Green synthesis, toxicity evaluation and new insights in biomedical applications. J. Alloy. Compd. 2021, 876, 160175. [CrossRef]

14. Priya; Naveen; Kamaljit, K.; Amanpreet, S.K. Green synthesis: An eco-friendly route for the synthesis of iron oxide nanoparticles. Front. Nanotechnol. 2021, 3, 47. [CrossRef]

15. Muthuvelu, K.S.; Rajarathinam, R.; Selvaraj, R.N.; Rajendren, V.B. A Novel method for improving laccase activity by immobilization onto copper ferrite nanoparticles for lignin degradation. Int. J. Biol. Macromol. 2020, 152, 1098-1107. [CrossRef]

16. Carvalho, P.M.; Felício, M.R.; Santos, N.C.; Gonçalves, S.; Domingues, M.M. Application of light scattering techniques to nanoparticle characterization and development. Front. Chem. 2018, 6, 237. [CrossRef] [PubMed]

17. Bhattacharjee, S. DLS and zeta potential—What they are and what they are not? J. Control. Release 2016, 235, 337-351. [CrossRef] [PubMed]

18. Cho, E.J.; Jung, S.; Kim, H.J.; Lee, Y.G.; Nam, K.C.; Lee, H.J.; Bae, H.J. Co-immobilization of three cellulases on Au-doped magnetic silica nanoparticles for the degradation of cellulose. Chem. Commun. 2012, 48, 886-888. [CrossRef]

19. Zhang, Q.; Kang, J.; Yang, B.; Zhao, L.; Hou, Z.; Tang, B. Immobilized cellulase on Fe3O4 nanoparticles as a magnetically recoverable biocatalyst for the decomposition of corncob. Chin. J. Catal. 2016, 37, 389-397. [CrossRef]

20. Bohara, R.A.; Thorat, N.D.; Pawar, S.H. Immobilization of cellulase on functionalized cobalt ferrite nanoparticles. Korean J. Chem. Eng. 2016, 33, 216-222. [CrossRef] 
21. Han, J.; Luo, P.; Wang, Y.; Wang, L.; Li, C.; Zhang, W.; Dong, J.; Ni, L. The development of nanobiocatalysis via the immobilization of cellulase on composite magnetic nanomaterial for enhanced loading capacity and catalytic activity. Int. J. Biol. Macromol. 2018, 119, 692-700. [CrossRef]

22. Koo, N.K.; Ismail, A.F.; Dzarfan, M.H.; Rahman, M.A.; Sheng, T.Z. Preparation and characterization of superparamagnetic magnetite (Fe3O4) nanoparticles: A short review. Mal. J. Fund. Appl. Sci. 2019, 15, 23-31. [CrossRef]

23. Netto, C.G.C.M.; Toma, H.E.; Andrade, L.H. Superparamagnetic nanoparticles as versatile carriers and supporting materials for enzymes. J. Mol. Catal. B Enzym. 2013, 85, 71-92. [CrossRef]

24. Malhotra, N.; Lee, J.S.; Liman, R.; Ruallo, J.; Villaflores, O.B.; Ger, T.R.; Hsiao, C.D. Potential toxicity of iron oxide magnetic nanoparticles: A review. Molecules 2020, 25, 3159. [CrossRef] [PubMed]

25. Reddy, L.H.; Arias, J.L.; Nicolas, J.; Couvreur, P. Magnetic nanoparticles: Design and characterization, toxicity and biocompatibility, pharmaceutical and biomedical applications. Chem. Rev. 2012, 112, 5818. [CrossRef] [PubMed]

26. Sandler, S.E.; Fellows, B.; Mefford, T. Best practical for characterization of magnetic nanoparticles for biomedical applications. Anal. Chem. 2019, 91, 14159-14169. [CrossRef] [PubMed]

27. Mika, N.; Zorn, H.; Rühl, M. Insect-derived enzymes: A treasure for industrial biotechnology and food biotechnology. Adv. Biochem. Eng. 2013, 136, 1-17. [CrossRef]

28. Lima, J.S.; Araújo, P.H.H.; Sayer, C.; Souza, A.A.U.; Viegas, A.C.; de Oliveira, D. Cellulase immobilization on magnetic nanoparticles encapsulated in polymer nanospheres. Bioproc. Biosyst. Eng. 2017, 40, 511-518. [CrossRef]

29. Shinkai, M.; Honda, H.; Kobayashit, T. Preparation of fine magnetic particles and application for enzyme immobilization. Biocatalysis 1991, 5, 61-69. [CrossRef]

30. Valenzuela, R.; Castro, J.F.; Parra, C.; Baeza, J.; Durán, N.; Freer, J. $\beta$-Glucosidase immobilisation on synthetic superparamagnetic magnetite nanoparticles and their application in saccharification of wheat straw and Eucalyptus globulus pulps. J. Exp. Nanosci. 2014, 9, 177-185. [CrossRef]

31. Alahakoon, T.; Koh, J.W.; Chong, X.W.C.; Lim, W.T.L. Immobilization of cellulases on amine and aldehyde functionalized Fe2O3 magnetic nanoparticles. Prep. Biochem. Biotechnol. 2012, 42, 234-248. [CrossRef]

32. Alftrén, J.; Hobley, T.J. Immobilization of cellulase mixtures on magnetic particles for hydrolysis of lignocellulose and ease of recycling. Biomass Bioenergy 2014, 65, 72-78. [CrossRef]

33. Zhang, W.; Qiu, J.; Feng, H.; Zang, L.; Sakai, E. Increase in stability of cellulase immobilized on functionalized magnetic nanospheres. J. Magn. Magn. Mater. 2015, 375, 117-123. [CrossRef]

34. Baskar, G.; Naveen Kumar, R.; Heronimus Melvin, X.; Aiswarya, R.; Soumya, S. Sesbania aculeata biomass hydrolysis using magnetic nanobiocomposite of cellulase for bioethanol production. Renew. Energy 2016, 98, 23-28. [CrossRef]

35. Jia, J.; Zhang, W.; Yang, Z.; Yang, X.; Wang, N.; Yu, X. Novel magnetic cross-linked cellulase aggregates with a potential application in lignocellulosic biomass bioconversion. Molecules 2017, 22, 269. [CrossRef] [PubMed]

36. Chen, Q.; Liu, D.; Wu, C.; Yao, K.; Li, Z.; Shi, N.; Wen, F.; Gates, I.D. Co-immobilization of cellulase and lysozyme on aminofunctionalized magnetic nanoparticles: An activity-tunable biocatalyst for extraction of lipids from microalgae. Bioresour. Technol. 2018, 263, 317-324. [CrossRef] [PubMed]

37. Sillu, D.; Agnihotri, S. Cellulase immobilization onto magnetic halloysite nanotubes: Enhanced enzyme activity and stability with high cellulose saccharification. ACS Sustain. Chem. Eng. 2020, 8, 900-913. [CrossRef]

38. Xu, C.; Chen, X.; Zheng, R.; Zheng, Y. Immobilization of multi-enzymes on supports materials for efficient biocatalysis. Front. Bioeng. Biotechnol. 2020, 8, 660. [CrossRef] [PubMed]

39. Liao, H.; Chen, D.; Yuan, L.; Zheng, M.; Zhu, Y.; Liu, X. Immobilized cellulase by polyvinyl alcohol/ $\mathrm{Fe}_{2} \mathrm{O}_{3}$ magnetic nanoparticle to degrade microcrystalline cellulose. Carbohydr. Polym. 2010, 82, 600-604. [CrossRef]

40. Gokhale, A.A.; Lu, J.; Lee, I. Immobilization of cellulase on magneto responsive graphene nano-supports. J. Mol. Catal. B Enzym. 2013, 90, 76-86. [CrossRef]

41. Kudina, O.; Zakharchenko, A.; Trotsenko, O.; Tokarev, A.; Ionov, L.; Stoychev, G.; Puretskiy, N.; Pryor, S.W.; Voronov, A.; Minko, S. Highly efficient phase boundary biocatalysis with enzymogel nanoparticles. Angew. Chem. Int. Ed. 2014, 53, 483-487. [CrossRef] [PubMed]

42. Zang, L.; Qiu, J.; Wu, X.; Zhang, W.; Sakai, E.; Wei, Y. Preparation of magnetic chitosan nanoparticles as support for cellulase immobilization. Ind. Eng. Chem. R. 2014, 53, 3448-3454. [CrossRef]

43. Sánchez-Ramírez, J.; Martínez-Hernández, J.L.; Segura-Ceniceros, P.; López, G.; Saade, H.; Medina-Morales, M.A.; RamosGonzález, R.; Aguilar, C.N.; Ilyina, A. Cellulases immobilization on chitosan-coated magnetic nanoparticles: Application for Agave Atrovirens lignocellulosic biomass hydrolysis. Bioproc. Biosyst. Eng. 2017, 40, 9-22. [CrossRef] [PubMed]

44. Mo, H.; Qiu, J. Preparation of chitosan/magnetic porous biochar as support for cellulase immobilization by Using glutaraldehyde. Polymers 2020, 12, 2672. [CrossRef] [PubMed]

45. Qi, B.; Luo, J.; Wan, Y. Immobilization of cellulase on a core-shell structured metal-organic framework composites: Better inhibitors tolerance and easier recycling. Bioresour. Technol. 2018, 268, 577-582. [CrossRef] [PubMed]

46. Ulaganathan, K.; Goud, B.S.; Reddy, M.M.; Kumar, V.P.; Balsingh, J.; Radhakrishna, S. Proteins for breaking barriers in lignocellulosic bioethanol production. Curr. Protein Pept. Sc. 2015, 16, 100-134. [CrossRef] [PubMed]

47. Bhattacharya, A.; Pletschke, B.I. Magnetic cross-linked enzyme aggregates (CLEAs): A novel concept towards carrier free immobilization of lignocellulolytic enzymes. Enzym. Microb. Technol. 2014, 61, 17-27. [CrossRef] 
48. Soozanipour, A.; Taheri-Kafrani, A.; Landarani Isfahani, A. Covalent attachment of xylanase on functionalized magnetic nanoparticles and determination of its activity and stability. Chem. Eng. J. 2015, 270, 235-243. [CrossRef]

49. Landarani-Isfahani, A.; Taheri-Kafrani, A.; Amini, M.; Mirkhani, V.; Moghadam, M.; Soozanipour, A.; Razmjou, A.; Taheri-Kafrani, A. Xylanase immobilized on novel multifunctional hyperbranched polyglycerol-grafted magnetic nanoparticles: An efficient and robust biocatalyst. Langmuir 2015, 31, 9219-9227. [CrossRef]

50. Perwez, M.; Ahmad, R.; Sardar, M. A reusable multipurpose magnetic nanobiocatalyst for industrial applications. Int. J. Biol. Macromol. 2017, 103, 16-24. [CrossRef]

51. Kumari, A.; Kaila, P.; Tiwari, P.; Singh, V.; Kaul, S.; Singhal, N.; Guptasarma, P. Multiple thermostable enzyme hydrolases on magnetic nanoparticles: An immobilized enzyme-mediated approach to saccharification through simultaneous xylanase, cellulase and amylolytic glucanotransferase action. Int. J. Biol. Macromol. 2018, 120, 1650-1658. [CrossRef] [PubMed]

52. Periyasamy, K.; Santhalembi, L.; Mortha, G.; Aurousseau, M.; Boyer, A.; Subramanian, S. Bioconversion of lignocellulosic biomass to fermentable sugars by immobilized magnetic cellulolytic enzyme cocktails. Langmuir 2018, 34, 6546-6555. [CrossRef] [PubMed]

53. Hwangbo, M.; Tran, J.L.; Chu, K.H. Effective one-step saccharification of lignocellulosic biomass using magnetite-biocatalysts containing saccharifying enzymes. Sci. Total Environ. 2019, 647, 806-813. [CrossRef] [PubMed]

54. Mehnati-Najafabadi, V.; Taheri-Kafrani, A.; Bordbar, A.K. Xylanase immobilization on modified superparamagnetic graphene oxide nanocomposite: Effect of PEGylation on activity and stability. Int. J. Biol. Macromol. 2018, 107, 418-425. [CrossRef]

55. Paz-Cedeno, F.R.; Carceller, J.M.; Iborra, S.; Donato, R.K.; Godoy, A.P.; Veloso de Paula, A.; Monti, R.; Corma, A.; Masarin, F. Magnetic graphene oxide as a platform for the immobilization of cellulases and xylanases: Ultrastructural characterization and assessment of lignocellulosic biomass hydrolysis. Renew. Energy 2021, 164, 491-501. [CrossRef]

56. Ariaeenejad, S.; Motamedi, E.; Hosseini Salekdeh, G. Immobilization of enzyme cocktails on dopamine functionalized magnetic cellulose nanocrystals to enhance sugar bioconversion: A biomass reusing loop. Carbohydr. Polym. 2021, 256, 117511. [CrossRef]

57. Pollegioni, L.; Tonin, F.; Rosini, E. Lignin-degrading enzymes. FEBS J. 2015, 282, 1190-1213. [CrossRef]

58. de Gonzalo, G.; Colpa, D.I.; Habib, M.H.M.; Fraaije, M.W. Bacterial enzymes involved in lignin degradation. J. Biotechnol. 2016, 236, 110-119. [CrossRef]

59. Voběrková, S.; Solčány, V.; Vršanská, M.; Adam, V. Immobilization of ligninolytic enzymes from white-rot fungi in cross-linked aggregates. Chemosphere 2018, 202, 694-707. [CrossRef]

60. Hu, J.; Yuan, B.; Zhang, Y.; Guo, M. Immobilization of laccase on magnetic silica nanoparticles and its application in the oxidation of guaiacol, a phenolic lignin model compound. RSC Adv. 2015, 5, 99439-99447. [CrossRef]

61. Amin, R.; Khorshidi, A.; Shojaei, A.F.; Rezaei, S.; Faramarzi, M.A. Immobilization of laccase on modified Fe3O4@SiO2@Kit-6 magnetite nanoparticles for enhanced delignification of olive pomace bio-waste. Int. J. Biol. Macromol. 2018, 114, 106-113. [CrossRef] [PubMed]

62. Vishnu, D.; Neeraj, G.; Swaroopini, R.; Shobana, R.; Kumar, V.V.; Cabana, H. Synergetic integration of laccase and versatile peroxidase with magnetic silica microspheres towards remediation of biorefinery wastewater. Environ. Sci. Pollut. R. 2017, 24, 17993-18009. [CrossRef] [PubMed]

63. Chen, X.; He, B.; Feng, M.; Zhao, D.; Sun, J. Immobilized laccase on magnetic nanoparticles for enhanced lignin model compounds degradation. Chin. J. Chem. Eng. 2020, 28, 2152-2159. [CrossRef]

64. Gou, Z.; Ma, N.L.; Zhang, W.; Lei, Z.; Su, Y.; Sun, C.; Wang, G.; Chen, H.; Zhang, S.; Chen, G.; et al. Innovative hydrolysis of corn stover biowaste by modified magnetite laccase immobilized nanoparticles. Environ. Res. 2020, 188, 109829. [CrossRef] [PubMed]

65. Shanmugam, S.; Krishnaswamy, S.; Chandrababu, R.; Veerabagu, U.; Pugazhendhi, A.; Mathimani, T. Optimal mmobilization of Trichoderma asperellum laccase on polymer coated Fe3O4@SiO2 nanoparticles for enhanced biohydrogen production from delignified lignocellulosic biomass. Fuel 2020, 273, 117777. [CrossRef]

66. Mariño, M.; Moretti, P.; Tasic, L. Immobilized commercial cellulases onto amino-functionalized magnetic beads for biomass hydrolysis: Enhanced stability by non-polar silanization. Biomass Conv. Bioref. 2021. [CrossRef] 